\title{
"Barwy Białe" on their Way to Aid Fighting Warsaw. The Crimes of the Home Army against the Jews
}

Having received the order from "Zawisza," Jan Stec ${ }^{1}$ and I gathered our platoons, comprising about 60 members of the Home Army in total, then went to the designated location in the Siekierno forest in the Kielce county, where we were brought by one of the Jews staying in "Zawisza's" headquarters. Once there, we saw about 30 Jewish people, including several women, in forest huts. I then gave an order to assemble them all and take them to a clearing. Next, when they were brought to that clearing, I ordered NCO weapons sergeant "Bolrok" ${ }^{2}$ to execute those Jews, and I walked away about forty feet into the woods, not wishing to watch the execution. After other members of the Home Army had shot those people, I came back from the forest into the clearing and saw dead Jews lying on the ground, and the soldiers killed those who were still alive with a few more shots. We were meant to bury them in that clearing, but a messenger arrived from "Zawisza" and told us to return to the squad immediately, which we did, leaving the murdered Jewish people unburied in a forest clearing in the forest near Siekierno in the Kielce county. ${ }^{3}$

This is the account of the events given by Edward Sternik "Grzegorz," interrogated by an investigating officer of the Provincial Public Security Office (Wojewódzki Urząd Bezpieczeństwa Publicznego, WUBP) in Kielce. The account addresses an execution carried out on defenseless Jews on 17 August $1944^{4}$ at the behest of Lieutenant Kazimierz Olchowik "Zawisza" by the "Barwy Białe" detachment. The detachment (as the $5^{\text {th }}$ company of the $2^{\text {nd }}$ Legions Infantry Regi-

\footnotetext{
${ }^{1}$ See biographical notes in alphabetical order at the end of the text.

${ }^{2}$ In the documents it is also spelled "Bojlrok," "Bojrok," and "Bolerok."

${ }^{3}$ Archiwum Instytutu Pamięci Narodowej Oddział w Kielcach [Archive of the Kielce Branch of the Institute of National Remembrance] (later: AIPN Ki), 013/25, file 2, Protokół przesłuchania podejrzanego z 31 III $1949 \mathrm{r}$. [Typescript of interrogation of the suspect on 31 March 1949], pp. 137-138.

${ }^{4}$ This is the most likely date, established on the basis of the calendar of movements of the $2^{\text {nd }}$ Legions Infantry Regiment of the Home Army, which stationed in Siekierno on 16 and 17 August 1944, and on the night of 17/18 August set off on their way. See Piotr Sierant, 2 Pułk Piechoty Legionów Armii Krajowej (Warsaw: Volumen-Bellona, 1996), 114.
} 
ment of the Home Army) was part of the $2^{\text {nd }}$ Infantry Division of the Home Army, commanded by Colonel Antoni Żółkiewski "Lina." The Division, which, following the order of the Chief of Home Army General Bór-Komorowski, marched to help fighting Warsaw.

The "Barwy Białe" partisan detachment, operating in the Kielce region, was already very controversial while still active. Władysław Zwiejski "Jaruga," the commander of the Opatów District of the Peasant Battalions, wrote about it on 5 March 1944:

[...] the name of the detachment is not accidental, but has a political meaning and simply smacks of provocation - and from the military point of view, it is harmful because it forces both the detachment members and the broad masses of organized and unorganized society to think of it as a political group. ${ }^{5}$

The detachment was established with the approval of the High Command of the Home Army in November $1943 .{ }^{6}$ It was a detachment directly subordinate to the Opatów District commander, Witold Sągajłło "Sulima." The first commander of the detachment was Lieutenant Konrad Suwalski "Mruk," formerly a member of the National Military Organization. ${ }^{7}$ The detachment recruited people from the town of Ćmielów and the surrounding area. At the beginning of 1944, Suwalski gained notoriety when he contacted German gendarmerie in Opatów. ${ }^{8}$ The talks, held in locations such as the estate of Karol T. Wickenhagen

\footnotetext{
${ }^{5}$ Archiwum Zakładu Historii Ruchu Ludowego [Archives of the Department of History of the People's Movement] (later: AZHRL), MiD III/18 "A," Sprawozdanie Jarugi do Komendy Okręgu III BCh [Jaruga's Report to the Command of the $3^{\text {rd }}$ District of the Peasant Battalions], 5 March 1944, p. 3.

${ }^{6}$ Witold Sagajllo, The Man in the Middle. A Story of the Polish Resistance 1940-1945 (London: L. Cooper-Secker \& Warburg, 1984), 121; Antoni Sułowski, U podnóża Gór Świętokrzyskich. Z dziejów obwodu Opatów ZWZ-AK 1939-1945 (Warsaw: PAX, 1987), 116; Wojciech Borzobohaty, "Jodła" Okręg Radomsko-Kielecki ZWZ-AK 1939-1945 (2 ${ }^{\text {nd }}$ edition, Warsaw: PAX, 1988), 45.

${ }^{7}$ National Military Organization (Narodowa Organizacja Wojskowa, NOW) was formed in October 1939 by the National Party (Stronnictwo Narodowe, SN). In November 1942 NOW was incorporated in the structures of the Home Army. SN activists and members of the NOW who did not accept the merger, in January 1943 appointed a new Supreme Board of the SN, and, together with the Lizard Union (Zwiqzek Jaszczurczy), military troops named National Armed Forces (Narodowe Siły Zbrojne, NSZ).

${ }^{8}$ AZHRL, MiD III, 18, Przejawy współpracy z Niemcami [Manifestations of collaboration with the Germans], no date, p. 4. The case became so famous that the commander of the Home Army Opatów District posted a message in the local edition of Biuletyn Informacyjny [Information Bulletin] (No. 19 of 17 February 1944), which read: "Explanation. In recent days, a rumor has been circulating that Polish organizations allegedly contacted and even entered into
} 
in Sobótka, were to be devoted to cooperation in the fight against the communist guerrillas. ${ }^{9}$

Several days later, on 12 February 1944 Suwalski carried out an unauthorized operation against a detachment of the People's Army named after Bartosz Głowacki in Wólka Bodzechowska. ${ }^{10}$ Some hostages captured during this operation, mostly Russians, were then executed at the behest of Lieutenant "Nurt" in Trukolasy by a platoon commanded by Warrant Officer Tomasz Waga "Czort."11 As a result, mutual bloodshed ensued, which did not cease despite the "truce" signed on February 25 between the Home Army and the People's Army. ${ }^{12}$ Suwalski's actions provoked widespread outrage in the Opatów District, and therefore, despite the initial resistance of the Home Army district commander, "Mruk" was removed from the command of the detachment. ${ }^{13}$

On 16 February 1944 the command of the "Barwy Białe" detachment was given to Władysław Pietrzykowski "Topór," previously the head of the $2^{\text {nd }}$ Home Army Department (Intelligence) in the Opatów District. Unlike Suwalski, Pietrzykowski directed his operations against the Peasant Battalions. In a report dated 5 March 1944 Zwiejski wrote:

friendly relations with the Germans. We hereby refute that. There can be no friendship with the eternal enemy, who has never missed any opportunity, and who does not miss it now, to destroy everything that is Polish. The source of the rumor is the Germans themselves. It is spread to shake the clear and steadfast attitude of the whole Polish nation. Therefore, we repudiate the evil insinuations and make it known to the less knowledgeable that it is our duty to continue to maintain our own balance and preservation of national dignity. Any tendencies towards the invaders from either the west, or east would be contrary to with tradition and our unyielding attitude, and consequently would undoubtedly prove to be fatal." Władysław Zwiejski "Jaruga" added the following commentary: "Characteristic moments: shifting the blame onto 'Polish organs.' Denial of 'friendship' - failure to mention the contacts. Given what has actually happened, this explanation is a cynical lie" (AHRL, MiD III/18 "A," Uzupełnienie [Supplement], no date, no pagination).

${ }^{9}$ Mieczysław Młudzik, Polem, lasem. Wspomnienia dowódcy oddziału partyzanckiego BCh-LSB ( $3^{\text {rd }}$ edition, Warsaw: Ludowa Spółdzielnia Wydawnicza, 1984), 117-122; Leszek Popiel, “Batalion partyzancki 2 pułku piechoty Leg. 'Nurt,'” Wojskowy Przegląd Historyczny 1 (1989): 186.

${ }^{10}$ Borzobohaty, "Jodła", 196.

${ }^{11}$ Popiel, "Batalion partyzancki," 185; see also: Archiwum Instytutu Pamięci Narodowej $\mathrm{w}$ Warszawie [Archive of the Institute of National Remembrance in Warsaw] (later: AIPN), GK, 411/216, Protokół przesłuchania podejrzanego Władysława Kolasy z 10 II 1949 r. [Typescript of interrogation of suspect Władysław Kolasa on 10 February 1949], p. 101.

${ }^{12}$ Bogdan Hillebrandt, Partyzantka na Kielecczyźnie 1939-1945 (Warsaw: Wydawnictwo MON, 1967), 250; Popiel, "Batalion partyzancki," 186.

${ }^{13}$ Suwalski, like his deputy, Lieutenant Aleksander Zalewski "Lisek," was demoted to the rank of gunner and incorporated into the detachment of "Nurt." The case of "Mruk" entailed the removal of "Sulima" from the position of the commander of the Opatów District Commandant (Popiel, "Batalion partyzancki," 186). 
As of 1 March 1944, a new and, I think, final stage began in the development of relations between the Union for Armed Struggle (Zwiqzek Walki Zbrojnej, ZWZ) and us. Having dispersed small groups of the Polish Workers' Party (Polska Partia Robotnicza, PPR), the "pacification" of the Peasant Battalions commenced that day. The district flying squad of the Home Army, currently under the command of Topór (the notorious Drewicz, as Mruk was stripped of the command for contacting and interacting with the Germans), was sent south with clear orders to pacify not just individuals from the Peasant Battalions, but entire units and detachments. ${ }^{14}$

On 17 February 1944 the "Barwy Białe" detachment stationed in the Kaliszany estate (property of Michał Leszczyński "Habdank") was joined by the members of the so-called special section of the $2^{\text {nd }}$ Home Army Department from the "300" Sub-district (Ćmielów): Władysław Kolasa "Leń," Władysław Cybula "Grzmot," and Ryszard Nowacki "Pobożny."15 Prior to joining the detachment (in April 1943), together with Stanisław Mroczek "Jastrząb" and Stanisław Tworek "Drozd," in the apartment of Maria Czuba in Goździelin, Bodzechów municipality, they murdered seven Jews, including two women and two children (aged 6 and 12 years). ${ }^{16}$ Mrs. Czuba's house was burnt. At the trial of Stanisław Różalski in 1959, Mrs. Czuba testified that she was approached by two Jewish women, who said they were from Bodzechów, and that their name was Rochamul, and that later, the Home Army people brought Frajda from Goździelin. ${ }^{17}$ She testified further that people were saying that the murdered Jews were from

${ }^{14}$ AZHRL, MiD III/18, Sprawozdanie Jarugi do Komendy Okręgu III BCh [Jaruga's report to the Command of the $3^{\text {rd }}$ District of the Peasant Battalions], 5 March 1944, p. 1. Zwiejski was critical of the "Barwy Białe," just as of the entire ZWZ-AK in the Opatów District, also after WWII. See Władysław Zwiejski, Walczyli w Chłopskich Batalionach. Z dziejów podziemnego ruchu ludowego w obwodzie opatowskim (1939-1944) (Warsaw: Ludowa Spółdzielnia Wydawnicza, 1964), 243-257.

${ }^{15}$ Marian Tadeusz Mazur (“Bończa”), Szumiały nam świętokrzyskie jodły (Katowice [1992]), 131.

${ }^{16}$ AIPN, GK, 411/216, Protokół przesłuchania podejrzanego Władysława Kolasy z 3 VI 1949 r. [Typescript of interrogation of suspect Władysław Kolasa on 3 June 1949], pp. 129130. Władysław Kolasa testified, moreover, that in the summer of 1943 the murders were committed of Chaja and Ałte Goldman (husband and wife) near railway tracks between Grójec and Brzustowa, Ćmielów district. The murder was allegedly committed by members of the Home Army from Ostrowiec: Marian Błażejewski "Maria," Jerzy Skwarek "Luks," Czesław Szymański “Wiara," Jerzy Żak, and Zygmunt Nowakowski "Ładny” (ibidem, p. 131).

${ }^{17}$ The Cytrynbaum family lived in Goździelin. Their names could be established on the basis of the database of Holocaust victims posted on the Yad Vashem website. Frajda was born in 1914, Rywka in 1884, Dovid in 1872, Mosze in 1917, and David in 1882. Also living in the same village were the Morgens (Bluma, Szmuel, and one person of unknown name), and the Weinrybs (Izaak, Aron, and Chaja), as well as Hena Grosman. See: http://www.yadvashem.org/ wps/portal/!ut/p/_s.7_0_A/7_0_FL?last_name=\&first_name=\&location=Gozdzielin\&next_ form=results, retrieved 30 August 2011. See also footnote 60 . 
Goździelin, Denkówek, Bodzechów, and Zygmuntówka. ${ }^{18}$ The head of the operation was Stanisław Różalski "Grażyna," subordinate of Józef Radomski "Robak," head of the Home Army intelligence in the Ćmielów Sub-district.

During the investigation and trial one of the perpetrators of the murder, Stanisław Tworek "Jaszczurka," testified that the operation was ordered by the head of the $2^{\text {nd }}$ Home Army Department in the "300" Sub-district (Ćmielów), Jan Szpinek "Motyl." It could be confirmed by another person involved in the murder, Stanisław Mroczek "Jastrząb." Since Mroczek had died in 1946, Szpinek never admitted that he had indeed issued such order. During interrogation he repeatedly stressed that the murder in Goździelin was a consequence of an instruction of the Opatów District command, supposedly ordering "all members of units to patrol their respective areas and liquidate the hiding Jews, who had allegedly committed theft." ${ }^{19}$ After World War II the above-named were brought to trial for the aforementioned crime. The explanatory memorandum to the Supreme Court judgment of 6 March 1958, overruling the judgment of the court of first resort sentencing Jan Szpinek "Motyl" to ten years in prison, says that the judgment was based solely "on the testimony of the witness Stanisław Tworek," which "could not constitute a sufficient and convincing evidence as to the guilt of the accused." 20 The trial files do not contain the report of the exhumation. Such exhumation was said to have been carried out by the Cytrynbaum from Goździelin, who also moved the corpses of the victims to the cemetery, as testified by the head of the Goździelin village, Marceli Sternik (see Document No. 3, p. 446).

${ }^{18}$ Archiwum Instytutu Pamięci Narodowej Oddział w Lublinie Delegatura w Radomiu [Archive of the Lublin Branch of the Institute of National Remembrance, Representation in Radom] (later: AIPN Ra), 29/138, Zeznanie świadka Marii Czuby z 7 III 1959 r. [Testimony of witness Maria Czuba dated 7 March 1959], p. 64.

${ }^{19}$ AIPN Ki, 9/124, file 1, Protokół przesłuchania podejrzanego Jana Szpinka z 25 II 1951 r. [Typescript of interrogation of suspect Jan Szpinek on 25 February 1951], p. 255; see also trial files: AIPN Ki, 9/124, file 4, pp. 51-53, 55, 94-101, 169-171.

${ }^{20}$ AIPN Ki, 9/124, file 4, k. 169-171. The testimony of witness Tworek alias "Jaszczurka," the sentence reads, "concerning the VI.R.135/51 investigation and his explanation concerning the case number VI.R.129/51, which was the basis for the courts sentencing in the present case do not seem plausible given the significant differences between them. The explanation of Tworek alias 'Jaszczurka' concerning the VI.R.129/51/p. 142 investigation, and his testimony from the investigation into the case number VI.R.135/51/p. 48 imply that Tworek learned that Szpinek issued the order to liquidate the Jews directly from Szpinek himself, but at the hearing VI.R.129/51/p. 364 and during the investigation concerning the VI.R.135/51 case, when confronted with Szpinek (p. 263) witness Tworek testified that he learned that Szpinek had given the order to kill the Jews from Mroczek, and not directly from the Szpinek himself. In this last account, Tworek alias 'Jaszczurka' appears as only an indirect witness to the above circumstance. The direct witness was the aforementioned Mroczek, who was not even questioned in this case. The circumstance cannot be examined by direct questioning of the witness Mroczek because he has been dead since 1946" (ibidem, p. 170). 
In March 1944 "Barwy Białe" detachment was joined by the "Rogaci" detachment comprised of 25 men, mostly Home Army partisans from the Ostrowiec Świętokrzyski Sub-district (codename 100) ${ }^{21}$. Thus, the detachment doubled in size. Soon, however, tensions emerged between "Topór" and the partisans under his command. Tadeusz Mazur "Bończa" recalls, "He simply couldn't find common language with his men and didn't know how to approach them, which was of crucial importance in the guerilla warfare conditions." 22 This was one of the reasons why on 20 May Pietrzykowski was removed from his post by the new commander of the Opatów Home Army District, Jan Wojciechowski ("Ais," "Młodzian"), and Kazimierz Olchowik "Zawisza" was made the new commander. At the end of May, other people joined the detachment, including Edwad Sternik "Grzegorz."

Olchowik was born on 23 January 1910 in Grodno. In the realities of the Second Republic of Poland, he was considered to be educated - after graduating from the Adam Mickiewicz All-Boys' State School in Grodno, he spent three threemonth terms at the Faculty of Medicine of the Stefan Batory University in Vilnius. Before the war, he worked in the penitentiary system (see biography at the end of the article). In addition to the compulsory military service, he took part in numerous military training exercises and courses, and on 1 January 1935, he was promoted to second lieutenant of the reserve. ${ }^{23}$ He took part in the September Campaign, and on 9 September 1939 he was to be promoted to lieutenant. This appointment, which was supposed to be announced by the regiment commander Lt. Col. Antoni Żółkiewski, was carefully reviewed by the Home Army Chief Verification Committee in Germany. ${ }^{24}$ Doubts arose from the fact that it was granted at a time when the regiment was fully engaged defending itself. One day later, the $5^{\text {th }}$ Podhale Rifles Infantry Regiment practically ceased to exist, and Olchowik was captured by the Germans. After his release on 27 October he came to Ćmielów, which was the home of the family of his brother Leon (1907-1940), a constable of the National Police in Opatów, an Ostaszków prisoner, who was murdered shortly afterwards by the NKVD in Kalinin (now Tver). ${ }^{25}$

From 1942, Olchowik was responsible for organizing intelligence and fighting squads in the $2^{\text {nd }}$ Department of the Radom Region of the Home Army. He

\footnotetext{
${ }^{21}$ Mazur, Szumiały nam świętokrzyskie jodły, 131.

${ }^{22}$ Ibidem, 132.

${ }^{23}$ Ryszard Rybka, Kamil Stepan, Awanse oficerskie w Wojsku Polskim 1935-1939 (Cracow: Fundacja Centrum Dokumentacji Czynu Niepodległościowego, 2003), 98.

${ }^{24}$ Studium Polski Podziemnej [The Polish Underground Movement Study Trust] (later: SPP), KW 1, Weryfikacja żołnierzy AK [Verification of the Home Army soldiers], Teczka Kazimierza Olchowika [The File of Kazimierz Olchowik].

${ }^{25}$ Naznaczeni piętnem Ostaszkowa. Wykazy jeńców obozu ostaszkowskiego i ich rodzin, ed. Zuzanna Gajowniczek, Bernadetta Gronek, and Wanda Chudzik (Warsaw: Rytm, 2000), 223.
} 
wrote about himself, "In February 1944, I was arrested by the Gestapo and placed in a prison in Ostrowiec, from which I was then miraculously released."26 Details of this release were a source of much controversy at the time, as Zwiejski wrote during the occupation, ${ }^{27}$ and Kolasa testified after the war. ${ }^{28}$ Immediately after his release from prison, Olchowik joined the ranks of the "Barwy Białe" detachment, ${ }^{29}$ first as a training officer, and then the commander of the unit. From the very beginning, he commanded a lot of respect among the partisans. Tadeusz Mazur noted,

We broke away from "Topór," and the new commander, "Zawisza," was someone we really trusted from the beginning. I can also say with full conviction that the trust later developed into great mutual affection. "Zawisza" understood his soldiers and knew how to treat them, but that does not mean that he was lenient and indulgent - on the contrary, the discipline of the detachment increased significantly. ${ }^{30}$

${ }^{26}$ SPP, KW 1, Weryfikacja żołnierzy AK [Verification of the Home Army soldiers], Teczka Kazimierza Olchowika [The File of Kazimierz Olchowik], Życiorys [Biography], p. 2 (handwritten).

${ }^{27}$ Zwiejski wrote on 24 February 1944, "About 18 February this year, in a cell of the Union for Armed Struggle in Momina, there were two members with pseudonyms Wyrwa and Zawisza. About noon, a patrol arrived in Momina comprised of three gendarmes and several 'blue' policemen. Seeing the gendarmes, local members fled. The gendarmes opened fire. Two individuals mentioned above fled behind the barn. Seeing this, the gendarmes surrounded the barn and captured those individuals. They brought them into the apartment of our member, who lived in the same building as the gentleman with whom the captured individuals were living. After some light beating they were taken to Ostrowiec. Their handguns and grenades were taken from them. The gendarmes also wanted to take our member but one of the 'blue' policemen spoke for him, stating that he had nothing to do with the captured individual. On the third day, both individuals were released and came to the same gentleman in Momina. There they declared that they had been released on the basis that they presented themselves as members of Polish organizations fighting against communists, Bolsheviks, and bandits. They came back with weapons returned to them by the Germans." (AZHRL, MiD III/18, Przejawy współpracy z Niemcami [Manifestations of collaboration with the Germans], p. 1 [duplicate]).

28 "After joining the detachment, he told me that he had been caught by the Gestapo in Ostrowiec, arrested for about two weeks, after which he had been released along with 'Wyrwa', with whom he had been caught. I would like to add that the Gestapo released him giving him back his weapon because he said that was a friend of 'Mruk' [...]. After demobilization of the $2^{\text {nd }}$ Division of the Home Army at the end of December 1944, 'Zawisza' came to my house in civilian clothes and showed me a 'Parabellum' gun and a pass for that gun written in German, issued by the Gestapo in Ostrowiec" (AIPN Ki, 013/24 [27/III], file 1, p. 73).

${ }^{29}$ SPP, KW 1, Weryfikacja żołnierzy AK [Verification of the Home Army soldiers], Teczka Kazimierza Olchowika [The File of Kazimierz Olchowik], Życiorys [Biography], p. 2; Mazur, Szumiały nam świętokrzyskie jodły, p. 131.

${ }^{30}$ Mazur, Szumiały nam świętokrzyskie jodły, 131, 137. 
Until August 1944, the "Barwy Białe" detachment operated mainly in the Opatów District. It was highly mobile, and, above all else, it grew in strength. At that time, the number of its members rose to two hundred well-trained soldiers. The detachment carried out over a dozen major and minor military actions in which they killed several nearly twenty Germans. ${ }^{31}$

The problem with the commander of the "Barwy Białe" detachment was his incomprehensible, almost pathological hatred of Jews. It is evidenced by the following incident: at the end of June 1944 (the day of Corpus Christi?), he began suspecting that a doctor in his unit, second lieutenant of the Polish Army "Miś" (real name unknown - perhaps Jaśkowicz or Joskowicz), was a Jew. ${ }^{32}$ Olchowik ordered for a doctor to be called from Śmiłów-Binkowice, who arrived and carried out an "examination." It was held at "Zawisza's" headquarters in the presence of the commander, his deputy Roman Rożyński "Róg," and Edward Sternik "Grzegorz." ${ }^{33}$ The latter, after the verdict, which was tantamount to a death sentence for "Miś," was given the task of carrying it out. Along with "Jeleń" (Jan Śledź), "Toporek" (Henryk Wierzbiński), "Wyrwa" (Zbigniew Zawartko), and "Bystry" (Zygmunt Sieniek), they put the condemned man on a wagon, went to the forest, and shot him. As the defendants testified, "Miś" had been in the detachment for about a month, at least he had already been there when Olchowik took the command. Three people were punished by the court sentence for the murder of "Miś" - Edward Sternik, Jan Śledź, and Henryk Wierzbiński (for the information about the sentences see biographies at the end of the text).

During the Operation Tempest, the "Barwy Białe" detachment was incorporated into the $2^{\text {nd }}$ Legions Infantry Regiment of the Home Army as the $5^{\text {th }}$ Company of the $2^{\text {nd }}$ Battalion. On 2 August 1944, the "Zawisza" men arrived near the village of Łagowica-Pipała, the designated area of concentration. ${ }^{34}$ Partisan detachments, which were incorporated in the $2^{\text {nd }}, 3^{\text {rd }}$, and $4^{\text {th }}$ Legions Infantry Regiment of the Home Army, formed the $2^{\text {nd }}$ Legions Infantry Division of the Home Army "Pogoń," under the command of Colonel Antoni Żółkiewski "Lin." Following the request of General Mitrofanov (not Muratov, as is commonly believed) that Home Army troops go to the rear of the Red Army, on 9 August $2^{\text {nd }}$ Legions Infantry Regiment of the Home Army moved to the north side of the Świętokrzyskie Mountains and took up positions from the village of Kraszków

${ }^{31}$ Borzobohaty, "Jodła", 197.

${ }^{32}$ AIPN Ki, 126/117, Protokół przesłuchania podejrzanego Henryka Wierzbińskiego z 6 XII 1949 r. [Typescript of interrogation of suspect Henryk Wierzbiński on 6 December 1949], pp. 29-32.

${ }^{33}$ AIPN, GK, 411/216, Protokół przesłuchania podejrzanego Edwarda Sternika z 8 VI 1949 r. [Typescript of interrogation of suspect Edward Sternik on 8 June 1949], p. 171.

${ }^{34}$ Sierant, 2 Pułk Piechoty Legionów, 81. 
to Jeleniów. Two days later, in the evening of 11 August the regiment moved to the area of the villages of Jeziorko-Dębno-Wola Szczygiełkowa-Brandys. During the night of 15 and 16 August, carrying out the command of General Bór-Komorowski calling for a march to bring assistance to fighting Warsaw (operation codenamed "Zemsta" [Revenge]), $2^{\text {nd }}$ Legions Infantry Regiment of the Home Army moved to the village of Siekierno. ${ }^{35}$

During their stay in the village, soldiers of the "Barwy Białe" detachment captured four Jews in a forest while they were looking for food. ${ }^{36}$ They were brought to Olchowik, who thus learned that there was a group of 30 to 58 Jews hiding in the Siekierno forest, ${ }^{37}$ who had escaped from a labor camp in Skarżysko-Kamienna owned by an armament company HASAG. ${ }^{38}$ Forced labor camps located in the Radom district and working primarily for the defense industry were being quickly liquidated at the time due to the rapidly advancing Red Army offensive. This situation brought a number of opportunities to escape from the camp just before their liquidation or during it. Escapees sought refuge in large expanses of woodland; many of them came into contact with partisan troops of nearly all formations operating on that territory. It is already known from studies in recent years that in many cases such contact ended tragically for the Jews. Christopher Browning ${ }^{39}$ has also recently written about escapees from the camp in Starachowice, though he was not familiar with materials on post-war criminal trials, which are the source of information about the grim details of those crimes.

But to return to the events of August 1944. After interrogating the captured Jews, Olchowik ordered Sternik to organize a "liquidation" of the escapees. About 60 men from the "Barwy Białe" detachment went to the refugees' camp, having learned how to find it from the previously captured Jews, who were most likely, unaware of the situation. Then came the execution, the course of which was described at the beginning of this article. It was so brutal that even some members

\footnotetext{
${ }^{35}$ Ibidem, 114.

${ }^{36}$ AIPN Ki, 126/45, p. 93.

37 The lowest and highest number (respectively) mentioned in the testimonies of the accused.

${ }^{38}$ Large, privately owned defense company Hugo Schneider Aktiengesellschaft (HASAG) set up several gunpowder and ammunition factories within the General Government. These were: Kamienna, Kielce, and four plants in Częstochowa. The total number of Jewish prisoners employed there in the years 1942-1945 amounted to more than 42 thousand. Before the end of the war, some of the workers were deported to concentration camps in Buchenwald, Gross-Rosen and Ravensbrück, as well as Leipzig, where the head office of the HASAG was located. The HASAG factory in Skarżysko was liquidated in July 1944, and some prisoners managed to escape to the nearby forest. See Jacek Wijaczka, Grzegorz Miernik, "Żydowscy robotnicy przymusowi w zakładach zbrojeniowych HASAG w Generalnym Gubernatorstwie w czasie II wojny światowej," in Z przeszłości Żydów polskich. Polityka - gospodarka - kultura - społeczeństwo, ed. Jacek Wijaczka, and Grzegorz Miernik (Cracow: IPN, 2005), 181-203.

${ }^{39}$ Christopher R. Browning, Remembering Survival. Inside a Nazi Slave-Labor Camp (New York: W.W. Norton \& Company, 2010).
} 
of the expedition were unable to watch it. Shoes and clothing of the victims were brought to "Zawisza's" unit on the same day. About a fortnight later, on 1 September 1944 , Olchowik was dismissed as the commander of the $5^{\text {th }}$ company and transferred to the command of the $2^{\text {nd }}$ Division of the Home Army as a liaison officer. ${ }^{40}$ Was the decision related to the events in Siekierno? Everything seems to indicate that it was, although it is difficult find actual sources to confirm this assumption. After disbanding the $2^{\text {nd }}$ Legions Infantry Regiment of the Home Army, Olchowik was appointed as commander of the $2^{\text {nd }}$ Battalion with the task to lead it the area of Świętokrzyskie Mountains and disband it there.

Several years later, the Court of Appeal in Kielce tried and sentenced a number of people for the crime in Siekierno: Władysław Kolasa, Edward Sternik, Jan Śledź, Jan Górski, Stanisław Stec, and Jan Kawecki (see biographies at the end of the text). The judgment reads:

According to their statements, the line of conduct of their commanders and their own criminal activities remained at odds with their feelings and ideas of humanitarianism, which they have not yet lost completely, but only as regards their own countrymen, while they had no inhibitions about murdering the Jews, whom they did not consider to be their kin $[\ldots] .{ }^{41}$

On 18 August the "Barwy Białe" detachment set of from Siekierno towards the town of Przysucha, designated as the new concentration region of the $2^{\text {nd }}$ Infantry Division. On 27 August 1944, given the need to break through the German defenses on the River Pilica, General "Bór" stopped the march to Warsaw and ordered the execution of tasks within the Operation Tempest. On 12 October the commander of the $2^{\text {nd }}$ Infantry Division, Colonel "Lin" Żółkiewski, suspended the $2^{\text {nd }}$ Legions Infantry Regiment of the Home Army as a tactical unit. ${ }^{42}$ Individual companies, including soldiers of the $5^{\text {th }}$ Company of the $2^{\text {nd }}$ Battalion, returned to their original location, namely to Opatów District. During this time, Lieutenant Michniewicz "Wyrwa," commander of a sapper platoon, shot with a machine gun three Jewish wagon drivers from the $2^{\text {nd }}$ Legions Infantry Regiment of the Home Army. "I saw that murder with my own eyes," Władysław Kolasa testified, "and it can be confirmed by each Home Army member from 'Zawisza's' detachment." ${ }^{33}$

${ }^{40}$ SPP, KW1, Weryfikacja żołnierzy AK [Verification of the Home Army soldiers], Teczka Kazimierza Olchowika [The File of Kazimierz Olchowik], Zaświadczenie weryfikacyjne [Verification certificate], p. 1.

${ }^{41}$ AIPN, GK, 217/45, p. 219.

${ }^{42}$ Sierant, 2 Pułk Piechoty Legionów, 232.

${ }^{43}$ AIPN, GK, 411/216, Protokół przesłuchania podejrzanego Władysława Kolasy z 10 II 1949 r. [Typescript of interrogation of suspect Władysław Kolasa on 10 February 1949], p. 102. 
The perpetrators of this crime have never been brought to justice, nor were the most important men - Kazimierz Olchowik and the sergeant nicknamed "Bolrok," who were guilty of murdering many innocent people. After World War Two, Olchowik managed to travel through Germany to England, and from there he went to Australia, where he died in 1979.44 The fate of "Bolrok," unfortunately, remains completely unknown.

Information on the murders committed by partisans from the "Barwy Białe" detachment on Jews in Goździelin, Lisowo, and Siekierno forests is virtually absent in the literature. Even Piotr Sierant's detailed and meticulously edited monograph of the $2^{\text {nd }}$ Legions Infantry Regiment of the Home Army, published in the 1990s, does not even make the slighted mention about it. Only Bogdan Hillebrandt in a monograph on guerrilla activity in the Kielce province- specifically, in a footnote - mentions the crimes in the Siekierno forest, reducing the number of victims to five. ${ }^{45}$ The political transformation in Poland meant that new publications have begun to appear, revealing a different picture of the Polish underground, particularly in relation to the extermination of the Polish Jews. Jadwiga Karolczak wrote a particularly important article, published in the special edition of Słowo Ludu, which focused on the crime in Zagórz near Daleszyce, committed by members of the "Wybraniecki" Home Army detachment. ${ }^{46}$ The author mentioned in it, inter alia, the murder in the Siekierno forest, committed by another Home Army unit with a characteristic name of "Barwy Białe."

Below, are presented fragments of source texts from extensive investigation materials and trial documentation kept in the archival resources of the Institute of National Remembrance. Investigation and prosecution materials have been found concerning Stanisław Różalski, ${ }^{47}$ Władysław Kolasa, ${ }^{48}$ Kazimierz Borkowski $^{49}$ (member of the Opatów "number two" Home Army unit), Aleksander Zalewski, ${ }^{50}$ and others; ${ }^{51}$ records of criminal cases of the District Military

${ }^{44}$ Mazur, Szumiały nam świętokrzyskie jodły, 228.

${ }^{45}$ Hillebrandt, Partyzantka na Kielecczyźnie, 293.

${ }^{46}$ Jadwiga Karolczak, "Duchy i upiory," Słowo Ludu. Magazyn, 21 August 1991: 6. More on the subject see the study by Alina Skibińska and Joanna Tokarska-Bakir, “'Barabasz' and the Jews: From the History of the 'Wybraniecki' Home Army Partisan Detachment" in this volume.

${ }^{47}$ AIPN Ki, 013/3635 (5422/III).

${ }^{48}$ AIPN Ki, 8/806 (SR 499/49); ibidem, 027/21 (27/III mf 22/3).

${ }^{49}$ AIPN Ra, 109/4.

${ }^{50}$ AIPN, GK, 411/216, parts 1-2, Prokuratura Sądu Okręgowego w Kielcach [Prosecutor's Office of the District Court in Kielce].

${ }^{51}$ AIPN Ki, 013/24 (27/III), files 1-2; ibidem, 013/25. 
Court against Władysław Kolasa ${ }^{52}$ and Stanisław Tworek's personal file ${ }^{53}$ (Security Service collaborator [tajny współpracownik, TW] "Kot"). However, the most important materials come from a criminal trial at the Appeals Court in Kielce against: Władysław Cybula, Jan Górski, Stanisław Gruszka, Stanisław Kawecki, Władysław Kolasa, Stanisław Kryj, Franciszek Łabuz, Stanisław Markiewicz, Ryszard Nowacki, Jan Stec, Edward Sternik, Jan Śledź, Henryk Wierzbiński, and Aleksander Zalewski, ${ }^{54}$ as well as from the trial of Stanisław Różalski. ${ }^{55}$ Investigation files and records from the criminal case have also been used against the members of the Opatów "number two" Home Army unit: Władysław Banaszek, Zenon Krzekotowski, Michał Pytlak, Józef Radomski and Jan Szpinek. ${ }^{56}$ Sentences in these cases are presented in biographical notes at the end of this study.

\section{SOURCE MATERIALS}

\section{Goździelin, March or April 1943}

\section{Witnesses}

1. Testimony of witness: Maria Czuba ${ }^{57}$

During the occupation, I lived in an isolated house outside of the village of Goździelin near the so-called pits, whose name comes from the nearby gorges. In these gorges, I saw Jews hiding after the displacement. I did not know the names of those Jews, I know that one of them was called "Majurek," and he was fat. In March and April 1943 in the evening, I cannot remember the actual date, several armed men came to my house, dressed in civilian clothes, who told me to immediately turn to face the wall of the house, which I did, seeing that they had weapons. One of these individuals, tall, dark, wearing a hat, spoke hoarsely, and stood beside me with a gun, and promised me that he would shoot me if I turn. At the same time, they put out all lights in the house. And so, standing against the wall, a few minutes later I heard that other individuals brought some other people, whom they lined by the opposite wall of the house and demanded money from them. As I realized, those captured people were Jews who had been hiding in the pits behind my house, because I then recognized the voice of that "Majurek" and one Jewish woman, who followed him. I don't know how many of these Jews there were because I was standing against the wall with my back to them. I only

${ }^{52}$ AIPN Ki, 8/806 (SR 499/49); ibidem, 126/48.

${ }^{53}$ AIPN Ki, 005/358 (2580/I).

${ }^{54}$ AIPN, GK, 217/45-47, 47a.

${ }^{55}$ AIPN Ra, 29/138.

${ }^{56}$ AIPN Ki, 9/123; ibidem, 9/126.

${ }^{57}$ AIPN, GK, 411/216, Protokół przesłuchania z 9 VIII 1949 r. w WUBP w Kielcach, oficer przesłuchujący Marian Duda [Typescript of the interrogation dated 9 August 1949 at the WUBP in Kielce, interrogating officer Marian Duda], pp. 30-31. 
understood that the Jews gave them the money that they had, because I heard the Jewess, who followed "Majurek," say that she had no more money. After taking the money, the bandits shot the Jews in my house against the wall, and, as they were leaving, they set fire to the house, which burnt down completely. On the following day after the incident, Germans came to me and asked me if I was the one to harbor those Jews, and who killed them.

2. Testimony of Maria Czuba at the main hearing ${ }^{58}$

During the occupation, I was hiding Jews in my house. It was in the spring of 1943, I do not remember the exact date, when someone started banging on the door to my house. I opened and a tall man entered. I do not know whether he had a gun, he told me to light a lamp and cover the window. In the doorway stood a Jewish woman who had been hiding in my house, when she wanted to cover the window, the man pushed her away, and he covered the window himself, at the same time forbidding me to turn around and to look out of the window. I turned to the wall and stood there, and all I could hear behind me at that time was footsteps. I do not know how many people then entered my home, because the whole time I had my face to the wall. I just heard Jews' moans and their voices: "Sir, sir, we are Polish." There was a man standing next to me, who then told me to keep my eyes behind the stove. One of the men shouted two times at the Jews to hand him their money, and the Jews did, and the tall one, who was standing next to me, asked how much they had given, the other told him it was enough, to which the Jews replied that they had no more, and only then did I hear the gun shots. How many Jews were there at the time in the house, I do not know, I dared not look back, I was so frightened. I just heard as one of the men asked the other if he should take the package. What that package was, I do not know. Then the man who was watching me told me to turn away from the stove and said, "And now, run away, woman, because tomorrow the Germans will come here and kill you." I walked right out of the house; I went to the dam, and lay there for quarter of an hour, barely conscious. When I got up, the house was on fire. Those people did not tell me before to take anything out of the house. Who set fire to the house, I do not know. I do not remember if any of them were in inside after I had left, or if I was the last one to come out of the house. I was completely unaware of my surroundings and perhaps I did not even notice. [...] From the time of my departure from the house to the time of the fire perhaps half an hour could have passed. I do not know who informed the Germans about the events in my place, I was not the one to report it.

${ }^{58}$ AIPN, GK, 217/45, Protokół rozprawy głównej przed Sądem Apelacyjnym w Kielcach $\mathrm{w}$ dniach 21-23 II $1950 \mathrm{r}$. [Typescript of the main hearing before the Court of Appeals in Kielce on February 21-23 1950], pp. 97-98. 
3. Testimony of Marceli Sternik ${ }^{59}$

During the German occupation, I was the head of the village of Goździelin. The murder of the Jewish people in the house of Maria Czuba and the burning of her house took place in the spring of 1943, at night; I do not remember a more accurate date. I was not informed about the house burning until the following day when German gendarmes came to me to take them to the site. Going with the gendarmes there, I found a burnt house, in the ruins of which the burnt corpses of seven men were found, one of which looked like a corpse of a small child, and the others looked like adults. The Germans asked Mrs. Czuba who had killed those people, and who those people were, and Mrs. Czuba said that they were Jews, killed by some individuals dressed in civilian clothes, who then burnt her house. The Germans ordered the bodies to be buried in a potato pit behind the burnt house, where they lay until the spring of 1945, that is until they were taken by some unknown persons of Jewish nationality from Bodzechów and the Cytrynbaum family from Goździelin ${ }^{60}$, who are probably now living in Kraków, I do not know the exact address.

\section{Testimony of Marceli Sternik at the main hearing ${ }^{61}$}

Then I saw the corpses. There were seven, I think, but they were just skeletons by then, six were larger, and one was small. [...] The Germans ordered me to take care of the burial of those skeletons. Before that, the Germans ordered me to search the burned rags, from which they took out two wads of dollars, but because they were burnt and worth nothing, they left them, and later children from the village played with them.

${ }^{59}$ AIPN, GK, 411/216, Protokół przesłuchania z 9 VIII 1949 r. w WUBP w Kielcach, oficer przesłuchujący Marian Duda [Typescript of the interrogation dated 9 August 1949 at the WUBP in Kielce, interrogating officer Marian Duda], pp. 28-29.

${ }^{60}$ Goździelin was the birthplace of the survivor Jankiel Cytrynbaum, b. in 1910 (Archiwum Żydowskiego Instytutu Historycznego [Archive of the Jewish Historical Institute; later: AŻIH], the Central Committee of Polish Jews [later: CKŻP], Wydział Ewidencji i Statystyki, Kartoteka Ocalałych z Zagłady [Department of Registration and Statistics, Index of Holocaust Survivors]). The records of the Jewish Committee in Ostrowiec contain an application of Majer and Jankiel Cytrynbaum, residing in Ostrowiec, Radomska St. 43, addressed to the State Board Liquidator, concerning the possession of the house with a garden in Goździelin at no. 81, pursuant to the judgment of the Municipal Court in Ostrowiec of 12 May 1945, and a letter of 18 April 1945 to the Municipal Court in Ostrowiec from the same persons, then living in Denków at Wesoła St. 13, concerning recovery of an oak cabinet with mirror from Eugenia and Jan Pronobis from Goździelin, who refuse to return it (AŻIH, Komitet Żydowski w Ostrowcu Świętokrzyskim [The Jewish Committee in Ostrowiec Świętokrzyski], 368/6).

${ }^{61}$ AIPN, GK, 217/45, Protokół rozprawy głównej przed Sądem Apelacyjnym w Kielcach $\mathrm{w}$ dniach 21-23 II $1950 \mathrm{r}$. [Typescript of the main hearing before the Court of Appeals in Kielce on 21-23 February 1950], p. 97. 


\section{Testimony of Józef Radomski ${ }^{62}$}

During the occupation, no one reported to me about any Jews hiding in the village of Goździelin, Bodzechów municipality, and I did not know that the Jews were hiding there. Sometime in 1943, I heard about a murder of Jews in the village of Goździelin. [...] I categorically declare that the murder of Jews in Goździelin was committed without my knowledge. I never ordered anyone to commit this murder. It is untrue that Różalski received a command-order from me to murder the Jews in Goździelin.

\section{The accused}

6. Testimony of Stanisław Tworek "Jaszczurka"63

In the spring of 1943, Stanisław Mroczek learned, but I do not know how, that in the village of Goździelin , in the house of a woman people called króli$c a$ [doe-rabbit], several Jews were hiding. The above fact was reported to Jan Szpinek "Motyl," who then ordered their liquidation. For the liquidation of the Jews from Bodzechów, he appointed Stanisław Mroczek and me, and then he left for Ćmielów. Who appointed the people from Ćmielów, I do not know, whether it was Szpinek or Radomski. In Ćmielów, Stanisław Różalski “Grażyna," Władysław Kolasa, Ryszard Nowacki, Władysław Cebula "Grzmot," and Głębicki, whose first name I do not remember were appointed for the liquidation. All of them came to the home of Stanisław Mroczek, and together we went to Goździelin. [...] The following day, Stanisław Mroczek and I were called by Jan Szpinek to Stanisław Różalski's place in Ćmielów. In this house, Jan Szpinek demanded our report of the operation we had carried out, because that morning we managed to learn that a lot of materials and money was burnt in that house, and therefore we reported it to Jan Szpinek. After receiving our report, Jan Szpinek began chastising Stanisław Różalski for not having searched the house thoroughly enough and not taking those things, instead of letting them burn.

7. Testimony of Władysław Kolasa at the main hearing ${ }^{64}$

Regarding the circumstances of the murder of seven Jews in Goździelin, Bodzechów municipality, I state the following: in the spring of 1943, I received a written order from the deputy company commander to go on my own to Bodzechów and there to await the arrival of "Grażyna." So I went there and waited, and eventually I was joined by Cybula and Nowacki. Then "Grażyna" came

${ }^{62}$ AIPN Ra, 29/138, Protokół przesłuchania z 17 III 1959 r. przez prokuratora wojewódzkiego w Kielcach Leona Śliwińskiego [Typescript of the interrogation dated 17 March 1959 carried out by the Provincial Prosecutor in Kielce, Leon Śliwiński], p. 74.

${ }^{63}$ AIPN Ra, 109/4, pp. 123-124.

${ }^{64}$ AIPN, GK, 217/45, Protokół rozprawy głównej przed Sądem Apelacyjnym w Kielcach $\mathrm{w}$ dniach 21-23 II $1950 \mathrm{r}$. [Typescript of the main hearing before the Court of Appeals in Kielce on 21-23 February 1950], pp. 81, 102-103. 
up to us - he was at that time the deputy company commander - and told us that we were ordered - he did not say by whom - to go and execute the Jews. "Grażyna" was my superior, deputy company commander, and I was obliged, as a soldier who had sworn obedience to his superiors, to obey the command. Nowacki, who came together with "Grażyna," was very drunk, he rode a bicycle. Before that, I had never seen Nowacki. We all went in the direction to where the Jews were supposed to be. Along the way, I was given a Mauser gun. When we reached the house where the Jews were said to be, "Grażyna" and Mroczek, who also were with us, went to the apartment, where there were three Jews, the rest of the Jews came out of hiding and entered the house. At that time, I was standing outside the house with Nowacki. What happened inside the house, I do not know, because I saw nothing. Since I did not know how to handle the gun I was given, Nowicki said he would show me how to use it and to this end we walked into the house. When we got there, we noticed that lights had been extinguished and there were already seven people shot dead, and one woman was alive. Who committed this murder, I do not know, because I did not see it with my own eyes, but I think it was "Grażyna" because he was the first to enter the house with Mroczek, and when I went there with Nowacki, it was all over. "Grażyna" took some money of the table, maybe 120-200 zlotys, whether the money belonged to the Jews, I do not know. It was not us who burnt the house afterwards. [...] As for the murder of Jews in Bodzechów, I was acting under duress and following orders, because, as I said, I was a soldier, who took the oath of obedience. If I had been ordered to beat the Jews, I cannot tell you what I would have done then, because I never received such a command.

[...]

I did not analyze this order then because I could not do so as a soldier. And today, after giving it a lot of thought, I know that from the point of view of a soldier I had to go there and follow the order, but from the human and humanitarian point of view - I condemn it and I think it was homicide. Even then I knew that to give such an order was a dreadful thing to do, but I was powerless to defy my orders as I had taken an oath of obedience and fidelity, which I had sworn to keep and stay in one organization. For disobeying an order I would have got a bullet in the head, because 'number two' was watching. Everyone was afraid of number two. Once, when he was staying in Ujazd, commander Topór saw a tipsy soldier, and he threatened to have him shot - he was so harsh, strict, and ruthless. I have not heard of anyone shot for moving from one detachment to another organization, but even though I have not heard about it, I cannot exclude that this might happen because we took an oath of allegiance to that very organization. [...]

The Hajgota Jews from Grójec were shot by some people from Ostrowiec, who were stationed there. It is quite possible that this was a Home Army group, which since moved to the National Armed Forces (Narodowe Sity Zbrojne, NSZ), as the Home Army were there at the time. 
8. Testimony of Ryszard Nowacki at the main hearing ${ }^{65}$

When we went to Bodzechów to eliminate these seven Jews, I was completely drunk. I went there at the command of "Grażyna" who was my direct superior. At that time, I belonged to the so-called special section. "Grażyna," when giving us an order, never said what operation we were going to and against whom, saying only that we are going to do "a job." I never thought about this in advance, what kind of job that it was, and did not do it then either. Before, I had drunk some vodka, and later still, on the way to Bodzechów, I drank more with "Grażyna" because I liked vodka. After drinking vodka, in the evening, we went to the village of Goździelin, where Kolasa, Cybula, Tworek and Mroczek were waiting for us at the track out of the village. Only then, after meeting with them, did "Grażyna" tell us all that we were going to liquidate the Jews who were hiding in the village. I do not remember now exactly whether we were assigned individual instructions. Then, we circled the house; I was standing in front of the house, while "Grażyna" and Mroczek went inside. The Jews themselves came out of hiding, there were several people. I do not remember whether someone else went into the house besides "Grażyna" and Mroczek. I do not know who was shooting in the house, because I was not here, I was standing in front of the house, I only heard gun shots. We did not set the house on fire. I went to the operation because it was an order, and I was used to the fact that an order is always right, plus I was very young and very drunk, after we passed Bodzechów I was not so much riding the bicycle as staggering, dragging the bicycle with me. [...] The special section was a group of people subject to the orders of number two. I belonged to this section by pure chance, because I followed Robak into the organization, and he was a member of number two, so I joined it as well. [...] I do not know why the Jews were shot in Goździelin, but why would it be impossible for the Jews to commit some act for which they should be punished. And I believed at that time that they must have committed such a criminal act and that was why they were shot, but today I do not believe this. [...] I said nothing in the investigation about robbing the murdered Jews of any money and sharing it, because I do not know whether any money was robbed at all or from whom. I have not heard of any robbery of Jewish property.

\section{Testimony of Władysław Cybula at the main hearing ${ }^{66}$}

Regarding the murder of the Jews in the village of Goździelin, I state as follows: I deny any involvement in this murder, and in any case, I am not guilty of it, but I merely admit that I took part in the deed. I do not remember exactly when

${ }^{65}$ AIPN, GK, 217/45, Protokół rozprawy głównej przed Sądem Apelacyjnym w Kielcach w dniach 21-23 II 1950 r. [Typescript of the main hearing before the Court of Appeals in Kielce on 21-23 February 1950], pp. 81-82.

${ }^{66}$ AIPN, GK, 217/45, Protokół rozprawy głównej przed Sądem Apelacyjnym w Kielcach $\mathrm{w}$ dniach 21-23 II $1950 \mathrm{r}$. [Typescript of the main hearing before the Court of Appeals in Kielce on 21-23 February 1950], p. 82. 
it was, but I received an order from Radomski - the municipality secretary - that I was to go to the village of Brzóstowa. He told me to report with "Grażyna." I carried out this order. After I reported with "Grażyna," he told me that we have to perform a certain task, he gave me a gun, and told me to meet Mroczek on a bridge near the village, where we to expect further orders together. By the said bridge, I met Mroczek, Kolasa, and sometime later - "Grażyna" himself, who told us that we were to go towards the village of Goździelin, but he did not tell us why. Nowacki was also there with us, very drunk. Only when we reached the village, did I hear from "Grażyna" that there were Jews hiding here, and that we were to eliminate them, but he did not say why. "Grażyna" with Mroczek entered the house, and the rest of us stayed outside, standing guard. After some time I walked into the house and glanced around. I noticed about four or five people and "Grażyna" who loaded the gun and started getting ready to shoot. I noticed a woman with her face to the wall, with Mroczek standing beside her. Seeing "Grażyna" preparing to shoot, I immediately withdrew from the house. After some time, "Grażyna" came out, carrying a bundle under his arm, I asked him to release me then, and I went home immediately. I did not notice then, on my way back, any fire glow; I heard later in the village that the woman - the owner of the house - set fire to the house at night herself. Some time later, I went to see Różalski ("Grażyna") and asked him why they had shot the Jews. He told me that it had been an order, only that too much ammunition was used and that they should have been executed some other way, silently. It was what the investigating officer who was interrogating me wrote down. I did not understand it then, I was only 21 , and trusted my commanders that what they were doing was good and right. I only found out that we were going to liquidate the Jews after we had arrived on site, I had no time to think about it, the Jews had already been brought to the house by that time. The first to go inside were "Grażyna" and Mroczek, myself, Nowacki and Kolasa stayed outside the house standing guard. Entering the house, I did not see any child there. I was only told about it by the investigating officer, that there was one child among them, so why would I deny it. I also do not remember whether Nowacki later went to the house. I was not analyzing the order given by the command of the division, I had no time for that, but I felt that something was wrong, since I went to "Grażyna" and I asked him why he had done it, to which he replied that is an order from the superiors. While in the detachment, I heard something about some operation in the Siekierno forest, but I was not a witness to it and I cannot say anything about it.

\section{Handwritten statement of Stanisław Różalski ${ }^{67}$}

At the Home Army outpost in Ćmielów, there was a special section to carry out tasks. Who was the commander, I do not know, but it was Radomski, alias

${ }^{67}$ AIPN Ra, 29/138, Własnoręczne oświadczenie podpisane przez Stanisława Różalskiego [Handwritten statement signed by Stanisław Różalski], Kielce, 25 February 1959, pp. 34-35. 
"Robak" who sent men to operations, and frequently stated that I was to lead the group. Officially, I was not informed that I was the commander of the Special Section. I do not remember exactly, it was in 1943 or 1944, sometime after the harvest, when Radomski alias "Robak" gave me an order to eliminate the Jews who were hiding in the village Goździelin. Radomski gave me some addresses where I was to look for hidden Jews, but now I do not remember them. Radomski did not tell me how many of these Jews were hiding but only where they assembled. Giving me the command to eliminate the said Jews, Radomski declared that they were working against us. Radomski also said with whom I was to go there, listing the names. As I recall, I was accompanied by Nowacki, Cybula "Jastrząb" from Bodzechów, and a few other men whom I do not remember now. Carrying out Radomski's order, we went to Goździelin. We went first to one, then another house, but we found no Jews there. I do not remember whether it was a Jew, or Jewess. In that house, we set up an ambush, and a moment later the Jews began to arrive there. As far as I remember, seven people came, Jewish men and women. If I recall, among them were three men, two women and two children. All the Jews were shot in this house. These Jews were shot by myself, Nowacki and Cybula. When killing the aforementioned Jews, I did not realize what I was doing. I was only concerned with carrying out the order. I knew that the order had to be carried out no matter what. Now, I am aware of that my deed was inhumane. I knew that the Jews were persecuted by the Germans. Killing the Jews, I tried to carry out the order. Some money and some rags were taken from those Jews. The money we spend on dinner, and we left the rags with Jastrząb in Bodzechów - they were of little value. At the time of the operation, I had a gun "Vis" in my possession. As I recall, Nowacki had a Parabellum gun, from which he also fired at the Jews. He said later that he tried out the gun that way.

\section{Testimony of Stanisław Różalski ${ }^{68}$}

I would like to state that at the time of the occupation I was a member of the Home Army in Ćmielów. The commander of my detachment (company) was Pękalski. Additionally, in the area of operations of Pękalski's company, also active was the Special Section led by Radomski alias "Robak." This section reported directly to the command in Ostrowiec. I sensed that Radomski had no relationship of dependency on Pękalski. I was not a member of the special section, but I used to be sent with that section on individual jobs. The basis for my involvement in the operations of the special section was that I was "sworn" (I gave my oath) by Radomski's predecessor, alias "Kościesza," whose name I do not know. In the month of April 1943, "Robak" gave me an order to eliminate the Jews living in Goździelin. [...] Other than that, I did not take part in any political or racial

${ }^{68}$ AIPN Ra, 29/138, Protokół przesłuchania z 26 II 1959 r. przez prokuratora wojewódzkiego w Kielcach L. Śliwińskiego [Typescript of the interrogation dated 26 February 1959, carried out by the Provincial Prosecutor in Kielce, Leon Śliwiński], pp. 34-36. 
killings. I was displeased with that order as well. I communicated my displeasure by telling Radomski that "an order is an order, but I wouldd rather not go." Radomski, giving me the command, said to shoot them all, big and small , that is to say both children and adults. The next day after I had received the order, Radomski came to me again and gave me detailed instructions, that is he set a meeting place and the time of assembly, as well as the place where we were to collect weapons, and time of the operation. The assembly was to be partly at my place in Ćmielów, and partly at the armoury in Bodzechów. According to the plan, on the same day Nowacki and Cybula reported with me, and together with them I went to Jastrząb residing in Bodzechow. At Jastrząb's house, I met with other men involved in the assignment. I was also Jastrząb's place from where we took the weapons. I had a "Vis," but I do not remember if it was my personal weapon, or whether I received it from Jastrząb. Everyone else also had a pistol. We left our bicycles at Jastrząb's, and on foot we went to Goździelin. We walked together. In that area, for example at the station in Bodzechów, German troops were stationed, but we walked together. I would like to add that we walked through the fields. We left Bodzechów at dusk, and soon we were in Goździelin, as the distance from Goździelin to Bodzechów is short - it is about 2 kilometers. [...] Radomski pointed us to three houses in Goździelin where Jews might be, and I knew exactly from Jastrząb in which house the Jews were, so I went to check two other houses just as a formality. Going into the houses, I did not say anything, just viewed the faces of people to see whether they looked Jewish. The third house, where there were Jews, was entered by two men who walked at the front of the group. Once they came back outside, they said that there was a Jew or Jewess in the house. I ordered some men to stay in hiding by the house, and myself, with Nowacki and Cybula, I entered the house. In the house, I indeed found a Jewish person. I do not remember now whether it was a man or a woman. Later, more Jews came to the house.

Altogether, seven Jews came to the house, including two children. One child around the age of 6 , the other about 12 . The adults were both men and women. There were 5 adults; I do not remember how many men, or how many women. We placed both the persons we found in the house, and the ones who entered the house later against the wall, facing it. To clarify, we did not place them this way, but we told them to stand like that. While they were standing like that, Nowacki began searching their belongings looking for money. How much money he took, I do not know. He took the money without my command. While Nowacki was looking for money, one Jewish woman accused us of being gangsters, but later she said that we were Poles and we would not do anything bad. We did not respond to her words. Soon after, we started to shoot. The first to shoot was Cybula, I was next. Nowacki initially did not want to shoot, but later said that he would try out his Parabellum, and also fired. I personally shot two Jews and one Jewess, but I do not remember exactly whether it was so. The children were shot by Cybula and Nowacki. At the time of shooting, the Jews were quiet in general, 
only one Jewish woman was screaming and the children were crying. I do not remember where I was aiming shots, think in the back. We did not finish those who fell to the floor. After we had stopped shooting, we immediately ran out of there. Nowacki and Cybula took bundles of clothing before leaving. We did not set fire to the house. When we were at a distance of about 1 kilometer, we saw that the house was on fire. I suppose that it was the owner of the house that set fire to it, fearing that the Germans would find the dead Jews there. [...] From Goździelin, we returned to Jastrząb's house in Bodzechów. Back at Jastrząb's place, Nowacki brought out the money he had taken and said that we would pay with that for supper. The money was taken by Jastrząb or his brother, who bought half a litre of vodka, and some sausage and bread. After the dinner, the local men went to their homes, and Nowacki, Cybula and I stayed at Jastrząb's house for the night, then in the morning we went back Ćmielów on our bicycles. I would like to add that giving me the order to shoot the Jews, Radomski said that we had to shoot them because they were harming our organization. I have no idea how the Jews, and especially small children could harm our organization.

12. Testimony of Stanisław Tworek ${ }^{69}$

I heard Różalski say that we would go to Mrs. Czuba to Goździelin to see what was happening there. Before this, Mroczek had informed Radomski alias Robak that citizen Czuba, residing in Goździelin, has some unknown people coming to her house, bringing packages. Mroczek wrote a report in my presence on this, which he then sent to Robak. I read that report. It did not say, however, that were Jews coming to Mrs. Czuba. Mroczek mentioned in the report that we should check what kind of people come to Czuba's, so going to the said operation, I was convinced that we were going to see what kind of people had come to Czuba's. [...] I was to watch the road at the exit of the village of Goździelin. [...] Mroczek was carrying two packages, as it turned out; it was the linen of the murdered Jews. We went to Mroczek's place, where Różalski searched the linen. Since it was of little value, so Różalski had Mroczek bury it. Mroczek buried the linen in his barn. As far as I could tell, there was also money taken from the murdered Jews. Różalski had the money, a total of about 200 zlotys (two hundred). [...] Among the rags there was an armband worn by the Jews in the ghettos. It seems to me that in Mroczek's house, Różalski searched some scraps of paper taken from murdered people. While he was looking through them, Różalski said that the people who had been shot were Jewish. While at Mroczek's place, Różalski cleaned his bloodstained trousers.

${ }^{69}$ AIPN Ra, 29/138, Protokół przesłuchania z 6 III 1959 r. przez prokuratora wojewódzkiego w Kielcach L. Śliwińskiego [Typescript of the interrogation dated 6 March 1959, carried out by the Provincial Prosecutor in Kielce, L. Śliwiński], p. 59. 


\section{Sentence}

13. Conclusion the judgment of the Provincial Court in Kielce ${ }^{70}$

The court finds Stanisław Różalski guilty as charged in the indictment and [...] and sentences him to 7 (seven) years in prison [...] and deprivation of his public rights and civil rights for a period of three years. He is charged with 800 zlotys of court fees and ordered to pay the costs of court proceedings.

\section{Conclusion the judgement of the Provincial Court in Kielce ${ }^{71}$}

As for the Jews hiding in Goździelin, the fact was known to the Home Army command, because, as witness Tworek, the commanding officer of the Home Army outpost in Bodzechow testified, Mroczek submitted the relevant report. If local members of the organization intended a robbery, they would certainly not have reported the Jews to their superiors. Also the accused could not have done it on his own initiative. Besides, killing in the form of an overt and formal operation precludes any action on their own. Such an act would be impossible to hide from the authorities and the culprits would have been severely punished. Contrary to the testimony of Radomski, one can hardly believe that he did not know about the operation in Goździelin, because due to the large number of casualties, the fire, the arrival of the Germans, it was very well known in the area, and Radomski after all was the head of intelligence in the sub-district where the operation took place. Anyway, this very same Radomski personally oversaw the actions of witness Cybula. All these circumstances in the Court's opinion clearly suggest that the accused Różalski is telling the truth and that he had been acting on orders received from Radomski. Undoubtedly, the Home Army authorities, based on Mroczek's reports, issued an order of liquidation of the Jews said to be guilty of robberies. Such commands ordering the liquidation of Jews in the Kielce Region recurred very often in a number of examined cases. [...] As for the plunder of the Jews, the accused should be believed that it was done by witness Nowacki on his own, who at the time of the operation was very drunk. The accused himself, being the owner of a shop, was not poor and would not be tempted by some clothes of hardly any value. Moreover, none of the witnesses has testified that the Jews had been searched before the shooting, and the following day children found burnt dollar bills. This fact clearly indicates that it was not about Jewish property. Clothes picked up by Nowacki were used to clean weapons, and the cash was spent on vodka. [...] Acting on orders does not relieve the accused from liability, and is only a mitigating circumstance. Moreover, the accused had a position of command and could have refused the order once he realized that there were Jewish women and small

${ }^{70}$ AIPN Ra, 29/138, Sentencja wyroku Sądu Wojewódzkiego w Kielcach z 25 III 1960 r., sędzia orzekający T. Bielski [Judgment of the Provincial Court in Kielce dated 25 March 1960, judge T. Bielski], p. 152.

${ }^{71}$ Ibidem, pp. 157-159. 
children, who could not have been dangerous and harmful for anyone but the Germans.

\section{The murder of "Miś," a member of the Home Army in a forest near Lisów, June 1944}

\section{Witnesses}

1. Testimony of Bolesław Kołbuc at the main hearing ${ }^{72}$

In 1944, I was on duty with my father, whom I was helping in the gamekeeper's cottage near the village of Lisów. Making our rounds in the forest one day, in the morning, we found blood and a freshly dug grave. [...] There was blood was beside the grave. We decided to investigate it. We went to the edge of the forest and towards Lisów, and meeting people, we asked them what was going on in the village. People said "Zawisza's" group was in the village, and that they had allegedly shot a Jew, a doctor who was a member of the group. We heard it from: Jan Kasiński, Mikołaj Kasiński, Józef Rzetelny, Jan Grad, and Maria Borkowska. It was a notorious affair in the village. They said that at first they had taken the doctor to the field, but too many people had been there, so they had gone to the forest. No one in the village was hired as a wagon driver. No one went to the forest to see what would happen. I marked the place where the grave used to be, but in the course of the war (trenches were dug in that forest) the area changed so much that in 1949, when the Security Bureau [Służba Bezpieczeństwa, UB] from Ostrowiec conducted a search with our involvement, we could find nothing anymore. Blood was also on the leaves of shrubs growing next to the grave at a height of 1 meter (it was a deciduous forest). I did not see bullet marks. We found the traces at 7 in the morning, and we talked to the people a little later, about 8 o'clock or 9 o'clock. People said that the doctor had been taken away the day before in the evening. We found the grave accidentally, it was masked with leaves, and the blood was partially scraped away. I was a member of the Peasant Battalions.

\section{Testimony of Bolesław Kołbuc at the main hearing ${ }^{73}$}

I heard from people in the village, namely Jan Kosiński [actual name Kasiński], Mikołaj Kosiński [actual name Kasiński] Jan Gradek [actual name Grad] and Bordowski that Zawisza's detachment held a court behind closed doors and that they were deciding what to do with the doctor. It was also there that he was sen-

${ }^{72}$ AIPN Ki, 126/117 (former Ref. GK, 217/117), Protokół rozprawy głównej przez Sądem Apelacyjnym w Kielcach w dniu 13 II 1950 r. [Typescript of the main hearing before the Court of Appeals in Kielce on 13 February 1950], pp. 59-60.

${ }^{73}$ AIPN, GK, 217/45, Protokół rozprawy głównej przed Sądem Apelacyjnym w Kielcach $\mathrm{w}$ dniach 21-23 II $1950 \mathrm{r}$. [Typescript of the main hearing before the Court of Appeals in Kielce on 21-23 February 1950], p. 101. 
tenced to death, although he apparently begged for his life. But Zawisza stood firmly by his decision. The, the Jew was taken on a wagon, and he allegedly tried to escape on the way, but the order was carried out. He was carried by men from Zawisza's detachment, but I do not know which ones. Zawisza stationed in the area at the time. [...] All the people in the village were curious and went to see the grave. [...] The Jew was rumored to have been examined earlier at Łukasiński's quarters [it says so in the text, it should be: in Krasiński's - J.M., A.S.].

The accused

3. Testimony of Władysław Kolasa ${ }^{74}$

While in "Zawisza's" detachment, in the month of May 1944 (at the end) our detachment was stationed in Lisów, Opatów county, and it was then that "Zawisza" ordered the killing of Second Lieutenant Dr. "Miś," who was a doctor in our detachment as a member of the Home Army. He was killed on suspicion that he was Jewish, and he was also accused that after inoculation of member[s] of the detachment against typhoid, a dozen of them had suffered as a result of swellings. I want to state that in spite of the ailment, none of the vaccinated died. I would like to add that before killing Dr. "Miś," on the same day the Home Army District Commander sent a doctor from Śmiłów, Opatów district, to our detachment, whose task was to determine whether Dr. "Miś" was actually of Jewish origin. And the Śmiłów doctor (whom I do not know at all) did, stating that Dr. "Miś" was indeed a Jew. Dr. "Miś" was executed in the Lisów forest, on the order of the commander of the Home Army detachment, "Zawisza," by four or five members of the same detachment, namely Jan Śledź, alias "Jeleń," "Bystry," "Os" (I do not remember exactly the other two), because at the time of the murder I was not present in the detachment (I was away on official business), and I learnt the above from "Jeleń's" account.

4. Testimony of Władysław Kolasa ${ }^{75}$

At first, having summoned some doctor from Śmiłów who said that Dr. "Miś" was a Jew, "Zawisza" wanted him to shoot himself, leaving him a gun and one bullet for this purpose. Seeing as Dr. "Miś" refused, he ordered his men to take him out into the forest and shoot him, which they did. On their way to the forest, they met the administrator from the Lisów estate, whom Dr. "Miś" asked to inform "Topór" that "Zawisza" had ordered him shot.

${ }^{74}$ AIPN, GK, 411/216, Protokół przesłuchania z 4 III 1949 r. w WUBP w Kielcach, starszy referent Ryszard Kuźdub [Typescript of the interrogation dated 4 March 1949 at the WUBP in Kielce, senior clerk Ryszard Kuźdub], p. 112.

${ }^{75}$ Ibidem, Protokół przesłuchania z 30 III 1949 r. w WUBP w Kielcach, oficer śledczy Stefan Barański [Typescript of the interrogation dated 30 March 1949 at the WUBP in Kielce, investigating officer Stefan Barański], p. 122. 


\section{Testimony of Edward Sternik ${ }^{76}$}

[...] there was a medical doctor in our detachment, alias "Miś," who, however, did not seem to be a real doctor. Rumors started to circulate in the detachment that he was not a doctor, but a German spy. Since scabies was spreading among the men, and "Miś" failed to cure them, commander "Zawisza" called for a doctor and we were all examined. After the examination, "Zawisza" called me and ordered me to go with soldiers, he did not say where, but he told me that the soldiers knew where we were to go or what to do. At that time, a wagon was already set up, on which a disarmed "Miś" was sitting with several soldiers. I climbed onto the wagon and we drove into the forest. [...] I would like to add that "Miś" had been in the detachment for about one month, and I even got along with him. I do not know if he was a Jew, and shooting him, I thought I was shooting a spy, exposed by the command. I did all those things following orders and fearing the consequences of disobeying an order, which was punished by death. I was not personally involved in shooting the Jewish population, and I could not bear to see it, I had to look away. I still cannot forget that event. My relationship with "Zawisza" was bad. I heard that "Zawisza" gave more such orders.

\section{Testimony of Edward Sternik ${ }^{77}$}

The examination of "Miś" was held at "Zawisza's" quarters, in the presence of Lieutenant "Róg," "Zawisza's" deputy, and myself. Then I was summoned once again by "Zawisza," who said that "Miś" would be executed. He personally designated men for this task, and "Miś" was already on a wagon, disarmed, guarded by Śledź alias "Jeleń," "Topór," "Wyrwa," and "Bystry." Following "Zawisza's" order, I went along on the aforementioned wagon to the forest behind the village of Lisów, where we were stationed at the time. While on the road, "Miś" knew we were going to shoot him and therefore he tried to flee, but he was captured and when we drove to the forest behind Lisów, "Miś" jumped out of the wagon and started to run, and then I first shot at him with a "Schmidt" gun, and at that point the others started shooting as well. As a result, "Miś" was shot, and then moved into the forest and buried. As regards "Miś," "Zawisza" told me that he was a German spy, but I heard from the soldiers in the detachment that "Zawisza" had told them that "Miś" left for some drinking den. But I suppose that people knew what the truth actually was.

${ }^{76}$ Ibidem, Protokół przesłuchania z 10 III 1949 r., prokurator Sądu Okręgowego w Kielcach Władysława Haśkiewiczowa [Typescript of the interrogation dated 10 March 1949, the prosecutor of the District Court in Kielce Władysława Haśkiewiczowa], p. 153.

${ }^{77}$ Ibidem, Protokół przesłuchania z 8 VI 1949 r. w WUBP w Kielcach, oficer śledczy Marian Duda [Typescript of the interrogation dated 8 June 1949 at the WUBP in Kielce, investigating officer Marian Duda], p. 171. 
7. Testimony of Edward Sternik at the main hearing ${ }^{78}$

The doctor did not fulfill his medical duties, and I saw it and reported it. For example, after he had administered a stomach-ache medicine, the patient's health deteriorated. "Zawisza" cautioned me not to talk to "Miś" too much about matters pertaining to the organization, since it was suspected that "Miś" was working for the German intelligence service. I do not know what nationality "Miś" was; he did not look like a Jew. In June 1944, the health of the detachment very visibly deteriorated (everyone in the detachment was riddled with scabies) in spite of "Miś's" treatment - another doctor came to us and said that the health of the detachment was unsatisfactory. After some time - we were in Lisów at the time - "Zawisza" called me into his quarters and said that "Miś" would be sent to the Home Army district quarters, and that he would be escorted by a group of soldiers. He told me that I, as an officer, would accompany them, since "Miś" was also an officer. I found "Miś" already disarmed. He was put onto a prepared wagon, drawn by a pair of horses. I was not told about the route and destination. Along the way, "Miś" began to show some concern and started to struggle and jump from the wagon - the soldiers held him still. Even previously, "Miś" had been warned, that is I had warned him on the wagon, as we were climbing on, not to try to escape because he would risk being shot. I do not recall whether I warned him on my own initiative, or at the behest of the commander. I do not know who was leader of the group escorting "Miś," and who was ordered to drive. I do not remember who led the way. Beside "Miś," the group included: myself, Sergeant Śledź, the accused [Henryk Wierzbiński], Platoon Sergeant "Bystry," and Corporal "Wyrwa." I do not remember how many men were there. I was not familiar with the route we were taking, through the village, then through the field, and into the forest. At one point, when we were near the forest, "Miś" jumped out of the wagon and began to run. Seeing that he could escape, I fired a shot in his direction from my "Smith" gun. Immediately after, I heard a machinegun burst. I did not see who was shooting. There was no order to fire. When "Miś" jumped off the wagon, all the soldiers jumped out after him. Śledź grabbed him, but "Miś" escaped and ran away. I shouted for him to stop, and fired a warning shot, but in my nervousness, I was not paying [attention] to the direction of the shot. "Miś" ran towards the field. I did not notice at which point he fell. When I fired a shot, I was about 30 meters from "Miś." The machine gun burst was discharged on my left, and the shooter was about 50 meters to the left from me, in the bushes. I do not remember if there was one source of the fire, or maybe two. "Miś" got several shots to the head and torso. After stating that he was dead, some men went to the neighboring houses to get shovels - we buried "Miss" in the forest about

${ }^{78}$ AIPN Ki, 126/117, Protokół rozprawy głównej przed Sądem Apelacyjnym w Kielcach w dniu 13 II 1950 r. [Typescript of the main hearing before the Court of Appeals in Kielce on 13 February 1950], p. 60 (Sternik testified as a witness in the criminal case of Henryk Wierzbiński). 
50 meters from the road and about 100 meters from the [edge of the] forest. We did not mark the place in any way. I do not remember whether we covered the grave with leaves. [...] I was assisting them on "Zawisza's" orders. I considered myself an escort and used the gun as per the regulation. I thought Miś was a spy based on my own observations. "Miś" lowered the combat value of troops administering them bad medicine. The incident was in the afternoon, around $4 \mathrm{pm}$. I do not remember who gave the order to bury him.

8. Testimony of Jan Górski at the main hearing79

"Miś" often went for a few days, ostensibly to Kalisz for new dressings. Since he would not come back for a long time, and there was something strange about his behaviour in general, we told "Zawisza" about this. What happened next, I do not know.

9. Testimony of Henryk Wierzbiński ${ }^{80}$

[...] I was called by "Zawisza" who told me to board the wagon and ride along with Second Lieutenant "Grzegorz." I would like to note that also already on that wagon, was Second Lieutenant "Miś," doctor of the Home Army detachment, dressed in military uniform, but without firearms and sitting beside him were: Second Lieutenant "Grzegorz," "Bystry," "Jeleń" and "Grześ," whom I joined. [...] "Grześ" said we were going to the command of the district, but where and which one - he do not say. On the road, Dr. "Miś" tried to flee, but he was captured by "Grzegorz" and again placed in the cart. In the meantime, driving past the estate behind the village of Lisów, Dr. "Miś" met an acquaintance of his from the estate, which I had not met, to whom Dr. "Miś" said, "tell (I do not remember whom) that Zawisza is going to have me shot." As the wagon approached the forest driving along a dirt road approximately one kilometer from the village of Lisów, Dr. "Miś" again tried to escape from the wagon and jumped down from the cart and ran away for about seven meters, Second Lieutenant "Grzegorz" gave orders to shoot and he shot first in the direction of the fleeing Dr. "Miś" with a "Schmitch" revolver. At the same time, I fired a burst from my own "Sten" automatic gun, with the result that Dr. "Miś" fell to the ground dead. After approaching the prostrate corpse of Dr. "Miś," we found that he was hit by a single bullet in the heart, possibly from the "Schmitch" revolver by "Grzegorz," and four bullets from the "Sten" machine gun, $9 \mathrm{~mm}$, in the left arm and head, where

${ }^{79}$ AIPN, GK, 217/45, Protokół rozprawy głównej przed Sądem Apelacyjnym w Kielcach w dniach 21-23 II 1950 r. [Typescript of the main hearing before the Court of Appeals in Kielce on 21-23 February 1950], p. 91.

${ }^{80}$ AIPN Ki, 126/117, Protokół przesłuchania z 5 XII 1949 r. w Powiatowym Urzędzie Bezpieczeństwa Publicznego w Ostrowcu, starszy oficer Jan Walaszczyk [Typescript of the interrogation dated 5 December 1949 at the District Public Security Bureau in Ostrowiec, senior officer Jan Walaszczyk], pp. 27-29. 
I had hit him. At that point, Dr. "Miś" was no longer moving. The statement by Second Lieutenant "Grzegorz" indicates that his shot proved fatal, which he expressed himself in these words: "I hit him straight in the heart." However, my shots hit the target and were fatal [...]. After killing Dr. "Miś," his corpse was stripped of clothing, that is his military uniform, trousers, and boots with tops in good condition, by Śledź alias "Jeleń" and "Grześ" and together they buried the corpse. [...] I observed from the fact that in the shoes of the slain Dr. "Miś" walked Śledź Jan "Jeleń," in uniform and trousers walked Różalski Jerzy alias "Sarna." I would like to add that I had not received any orders from Lt. "Zawisza" to eliminate Dr. "Miś," and the commander of the escort was Second Lieutenant "Grzegorz," and he apparently had received such an order, which I cannot confirm for certain. I was only there as an escort designated by "Zawisza" to help "Grzegorz," which I did. [...] I found that ["Miś"] as a man was very decent, amicable, peaceful, and did not demonstrate any major involvement in this organization, he was treating the sick members of the organization, but I do not know whether he was actually a doctor or not, because there were complaints about him by members he was treating that he treated them badly. Whether it is true that he was a Jew, I do not know, because I personally did not see. I would like to add that at the time of the crime, that identity papers were taken from Dr. "Miś," whose name, as I recall, was: Jaśkowicz, I do not remember his first name. These papers were taken by Second Lieutenant "Grzegorz," but what he did with them, I do not know.

\section{Testimony of Henryk Wierzbiński at the main hearing ${ }^{81}$}

Later I talked about it with the accused Śledź, and I said that it was a pity about that man, to which Śledź replied that if I felt sorry for him, then I should not have shot him. I know that everyone in the detachment complained about "Miś" that he was a bad doctor, the general opinion was that he was a spy for the Germans, and that is why his methods of treatment were bad. It was said that there was something suspicious about him, because from time to time he went to the city, and has some strange contacts, and he was bad at curing people. It all added up to a negative opinion of him. [...] The detachment, however, asked about him, if only because people saw his uniform and boots. After "Miś," his successor was doctor "Lepszy," ${ }^{2}$ a Jew, who indeed looked very much like a Jew, and

${ }^{81}$ AIPN GK, 217/45, Protokół rozprawy głównej przed Sądem Apelacyjnym w Kielcach w dniach 21-23 II 1950 r. [Typescript of the main hearing before the Court of Appeals in Kielce on 21-23 February 1950], p. 90.

82 "Lepszy" - a Jew, allegedly in "Zawisza's" detachment after "Miś" until the autumn of 1944. Wojciech Borzobohaty reports that Dr. "Lepszy" was Lieutenant Adam Brower-Paszkowski, doctor of the $1^{\text {st }}$ Battalion of the $4^{\text {th }}$ Legions Infantry Regiment of the Home Army. Based on the account by Jan Pękalski, Antoni Sułowski wrote that "after the liberation of Poland Dr. 'Lepszy' worked in Pruszków under the name of Paszkowski, gaining recognition among his patients. In 1958, it was revealed that he had not completed medical school 
people in the detachment talked openly about his background. Other than that, there was another Jew, Olsza ${ }^{83}$, who also looked like a Jew. They did not have any problems in the detachment on this account. [...] I am not sure if anyone other than "Grzegorz" and I shot at "Miś."

\section{Murder in the Siekierno forest, August 1944}

\section{Crime scene inspection report ${ }^{84}$}

In the course of the examination, it was found that in the Siekierno forest, Bodzentyn municipality, just 4 (four) kilometers from the village of Kaczka, in the Wąchock district, on a meadow, there is a mound with a boundary post separating the peasant meadow of the Siekierno village from the state-owned forest of the Kaczka 57 forest department - Siekierno forest inspectorate. As stated in the testimony of witnesses present at the burial of the victims and at today's visual inspection, the murder was committed in the area stretching from the boundary mound to two alders standing alone in a meadow, which is equal to a straight line 19 (nineteen) meters long, to the north-east. After the murder and stripping the bodies of clothes, the corpses were put on a pile in the forest, just 49 (forty nine) meters in a straight line from the border field to the northwest, and then moved and buried at a distance of 28 (twenty eight) meters away from the field border to the north. The grave itself, where, according to the witnesses' statement, about 50 (fifty) naked bodies were placed, is level with the rest of the area, only slightly concave towards the centre, making edges clearly marked. The area of the grave, which is 10 (ten) meters long and 2 (two) meters wide, is overgrown with lush bulrushes and other weeds. At a distance of 5 (five) meters from the grave, a wild old apple tree is growing, which is a tree rarely found in a forest. As the witnesses stated, the bodies of the murdered were stacked crosswise in the grave, and they have remained there till now, as confirmed by the smell released from the ground upon penetration.

\footnotetext{
and did not have a degree in medicine, for which he was prosecuted. However, later he did graduate from university and continued to work as a doctor" (Sułowski, U podnóża Gór Świętokrzyskich, p. 81).

83 "Olsza" - cadet in "Zawisza's" detachment; allegedly a Jew. He was in the detachment until demobilization in November 1944.

${ }^{84}$ AIPN, GK, 411/216, Protokół oględzin miejsca przestępstwa podpisany przez oficera śledczego WUBP w Kielcach Mariana Dudę [Crime scene inspection report signed by the investigating officer of the WUBP in Kielce, Marian Duda], Kaczka, 13 August 1949, p. 83 (the subsequent page contains a sketched map of the crime scene).
} 


\section{Witnesses}

2. Testimony of Stanisław Szumielewicz ${ }^{85}$

In July or August 1944, I cannot remember the exact date, one day I heard machine gun shots in the forest outside of the village, and it was said in the village said that they were shooting someone. On the second day, I went there, that is to the place where the shots were heard the day before, where, after a long search through the forest, together with Władysław Szumielewicz, Czesław Arend, and Henryk Ślęzak, all from the village of Stawek Stary, we found a pile of corpses of about 40-50 bodies. The corpses were stripped of clothes and lay naked. The pile was covered with branches on top, and stood at the edge of a forest meadow near the Siekierno forest, at a distance of three kilometers from the village of Kaczka. Having approached the pile of corpses, I noticed that there were also women among the men there. On their bodies, especially on their heads and chests, one could see bullet wounds, and they were bloodied all over. At the time when we were there, there was still a fire burning there, in fact it was glowing ashes - of the clothes of those dead, which we guessed from rags scattered around. On the third day after the shooting, the bodies were buried in the forest on the command of Polish partisans, in the same place where the pile had been. I remember that when I was there herding cows from a pasture, partisans told people to go to bury the corpses. [...] As I heard from some people, the murdered individuals were Jews from Skarżysko, who had escaped from the local munitions factory, the so-called "Hasag" [cf. footnote 38], and they had been hiding from the Germans in the forest near the village of Kaczka.

\section{Testimony of Władysław Młynarczyk ${ }^{86}$}

[...] When I was at home, two Polish partisans with weapons came to me, dressed in uniforms of the Polish Army, and instructed me to take a shovel and go with them to the forest. As I realized later on the way, they took also Stefan Malinowski, Stanisław Szumielewicz, and Mieczyslaw Babiarz, as well as some other people. We were led to the site of the alleged work by five partisans. Those partisans led us into the Siekierno forest, about 5 kilometers from the village of Kaczka, where we were ordered to dig a hole - as I now recall, about 3 meters wide, 3.5 meters long, and about 70-85 centimeters deep. Only after digging the hole were we shown a pile of human corpses, lying approximately 20 meters from the hole we had dug, stripped of clothes, stacked in the bushes by the forest meadows. We were ordered to bury those corpses in the hole we had dug. I do not remember now how many bodies there were, because I did not count them, but there could have been $40-50$ people. [...] The general view of

${ }^{85}$ AIPN, GK, 411/216, Protokół przesłuchania z 17 I 1949 r. w WUBP w Kielcach, oficer śledczy Marian Duda [Typescript of the interrogation dated 17 January 1949, at the WUBP in Kielce, investigating officer Marian Duda, pp. 71-72.

${ }^{86}$ Ibidem, pp. 73-74. 
the murder scene on the said meadow was shocking, as if it was something only the occupier could commit. About a hundred square meters of the meadow was drenched with curdled blood, on which hordes of flies were feasting, and in the bushes by the meadows - a pile of dead human bodies. As far as I could tell, the clothes of those murdered were burnt on site, as is evidenced by traces of fire in the meadow and unburned cloth strewn next to it. However, as I know from the account of Jan Stypuła from the village of Mostki, who is currently working in a factory somewhere in Kielce, at that time his wagon was seized with the horse, which the murderers used to transport the best garments from the forest, and that wagon with the horse has not been returned to Stypuła. The corpses of the victims bore the marks of machine gun bullets all over their bodies, and traces of blows, which indicated that they had been finished after shooting. [...] The partisans ordered us to drag the bodies to the hole we had dug, covered with dirt, level, without any mound. Before they released us from this work, the partisans standing over us told us not to talk about it to anyone, otherwise we were to expect a bullet in the head.

\section{The accused}

4. Testimony of Władysław Kolasa ${ }^{87}$

At a time when were stationed in Siekierno, four young Jews reported to the outpost, seeking food. The said Jews were detained and brought to the commander of the detachment, Lt. "Zawisza," who learned from them that there was a large group in the Siekierno forest. I do not know exactly whether it was in consultation and by the order of Col. "Kruk" that Lt. "Zawisza" murdered the Jews, or if he gave the order on his own initiative. "Zawisza," commander of the detachment, summoned Lt. "Grzegorz," platoon commander of "Zawisza's" detachment, and Lt. "Zygmunt," platoon commander of "Zawisza's" detachment. What instruction they received in this direction, the soldiers did not know. After assembling the platoons by these officers of "Zawisza's" detachment, the troops went into the Siekierno forest in a loose formation led by the Jews. At the site, in the forest, the troops found Jews of both sexes quartered there, with about 50 men and 6-8 women, including two girls. The Jews that had led us [the actual wording - J.M., A.S.] called the others in the forest, and led in twos out into a clearing, where Sergeant "Bolerok" was supposed to make a list of them. "Bolerok," in consultation with Lt. "Grzegorz" and Lt. "Zygmunt," selected people from the two platoons with machine guns and set them at a distance of four to five meters behind the Jews, who were standing with them back them. Upon a prearranged signal, by "Bolerok" raising his hand, a blast of machine gun was fired, and the murder was carried out. The firing squad consisted of about

${ }^{87}$ AIPN, GK, 411/216, Protokół przesłuchania z 24 I 1949 r. w WUBP w Kielcach, oficer śledczy Leon Barański [Typescript of the interrogation dated 24 January 1949 at the WUBP in Kielce; investigating officer Leon Barański], pp. 93-94. 
20 persons appointed by sergeant "Bolerok." I do not know those people, as they were from all over the place, including the demobilized, newly arrived to the detachment.

At the time when the execution was to take place, Lt. "Grzegorz," said to the members of the detachment that if someone cannot bear such things, he could go to the side. After these words, "Grzegorz" himself, as well as Lt. "Zygmunt" and several non-commissioned officers, including myself, alias "Leń," as a noncommissioned officer in the rank of platoon commander, and several soldiers from all squads, all moved aside. The execution was carried out immediately, so that the Jews did not even have time to realize what was going on.

5. Testimony of Władysław Kolasa ${ }^{88}$

Those, in turn, ["Grzegorz" and "Zygmunt"], after a long conversation with "Zawisza," gathered their platoons which were comprised of six squads, that is mine, "Żendzian's" [sic],"Bystry's," "Olsza's," "Jastrząb's" and "Lech's," together with those Jews, we went to the Siekierno forests, led by the Jews. Upon arrival on the site, the Jews called further fifty-four Jews, among whom there were eight women and two children. All those Jews came out of huts, in a line of two, and, as "Bolrok" assured them, they were to be enrolled in the Home Army organization. At the same time, "Bolrok" informed soldiers of all squads except "Olsza's," which was sent out to stand guard, that they were to line up behind the Jews and the moment when he raised his hand, they were to fire shots in their direction, which the men did. After firing the shots, some them were only wounded, so they were finished. After the murder, some of the dead were stripped of their shoes and clothes, and then we rejoined the detachment.

6. Testimony of Władysław Kolasa ${ }^{89}$

I would like to add that I was personally not involved in killing the Jews, and going to the place of execution, I was following the orders of Commander "Zawisza." I would like to explain refusing to follow an order was punished by a bullet to the head. I recall that Lieutenant "Grzegorz" said that those who cannot look at the execution should turn away, and after it was finished he said that it had been unnecessary and it had been horribly wrong.

${ }^{88}$ Ibidem, Protokół przesłuchania z 10 II 1949 r. w WUBP w Kielcach, starszy referent Ryszard Kuźdub [Typescript of the interrogation dated 10 February 1949 at the WUBP in Kielce, senior clerk Ryszard Kuźdub], pp. 101-102.

${ }^{89}$ Ibidem, Protokół przesłuchania 21 II 1949 r. przez p.o. podprokuratora L. Szelińską [Typescript of the interrogation dated 21 February 1949 by the acting assistant prosecutor L. Szelińska], pp. 114-115. 
7. Testimony of Władysław Kolasa at the main hearing ${ }^{90}$

As I have testified, a messenger came to me with instructions to leave the heavy weapons and go only lightly armed under the command of "Grzegorz." I joined the platoon as ordered, without any idea whatsoever of where we were going. Those four Jews were leading the way. The first group was led by "Bojrok," and the other by "Grzegorz." We all were under the command of "Grzegorz." We split into two groups only when we found out we were going to eliminate the Jews. I learned about this only when "Grzegorz" summoned the officers and asked them, who would accept the task of eliminating the Jews staying in the forest. Then "Bojlrok" volunteered, and he chose men himself. Then "Bojlrok" with those men went to the clearing where the Jews were camped, led them 500 meters into the forest, and them told them to line up at the edge of the forest. There were maybe 50 Jews, including four women. Cadet "Olsza" asked to be allowed to leave, for which he obtained consent. Besides, "Grzegorz" said himself that if someone couldn't bear to look at it, he might go, and he also walked away with Stec. The designated soldiers fire at the Jews standing in line. These four arrested Jews who had been leading us were also told to join the group of Jews. Then the Jews were stripped of clothing and footwear; the bodies were laid in a pile and left there. After this "Grzegorz" told us in the detachment that while "Zawisza" gave the order himself, he did a horribly wrong thing, because soldiers do not do things like that. He was very angry. The soldiers involved in the shooting explained that they had to follow the order. The four Jews who had led were liquidated last by "Bojlrok." The accused Stec was not involved at all, he was away from the incident. Sternik, Górski, Śledź, Kawecki, and Stec were in the forest at the time, but I do not know if they were shooting, because I did not see it.

\section{Testimony of Edward Sternik ${ }^{91}$}

Having returned from practice, I was summoned by the detachment commander, Lt. "Zawisza," who told me that there were some Jews in the forest near the village of Siekierno, released by the Germans from the camps, and that those Jews must be shot, which he ordered me to do, as I was a platoon commander. He assigned several men from "Longin's" platoon under my command for that purpose. At the same time, he mentioned that we would be shown the way to the place where the Jews were by a Jew who was in his quarters. My deputy at the time was S[t]ec. Jan Stec, alias "Zygmunt," who helped me form a platoon, including men from "Longinus's" platoon assigned to me, as well as others. As instruct-

${ }^{90}$ AIPN, GK, 217/45, Protokół rozprawy głównej przed Sądem Apelacyjnym w Kielcach w dniach 21-23 II 1950 r. [Typescript of the main hearing before the Court of Appeals in Kielce on 21-23 February 1950], p. 91.

${ }^{91}$ AIPN, GK, 411/216, Protokół przesłuchania z 10 VI 1949 r. w WUBP w Kielcach, oficer śledczy Marian Duda [Typescript of the interrogation dated 10 June 1949 at the WUBP in Kielce, investigating officer Marian Duda], pp. 172-173. 
ed, I took command of the entire group, with about sixty people at my disposal. Commanders of the squads at that time were: Kolasa alias "Leń," Górski alias "Rzędzian," Kawecki alias "Lech," and - if I am not mistaken - Olsza." Other than them, there were several non-commissioned officers from other platoons, such as "Bolrok," NCO in the rank of a weapons sergeant, and others whom I do not recall. Whether they had volunteered for the operation, or had been assigned by "Zawisza" - I do not know. Members of the detachment going to the said operation had been informed about its objective by "Zawisza" himself. Together, we went with the Jewish guide, who led us to the place, going into the forest about five kilometers to the west of the village of Siekierno. Approaching the camp where the Jews were living, we surrounded it, and then I, "Zygmunt," and a few others went inside the camp, which consisted of a few huts. There were men of different ages there, and several women among them. As far as I could tell, there were about twenty Jews there. As I recall, at the time when I was in the camp, shots were heard from the direction of our escort, and one Jew was shot in the hand. But I do not remember now who did it. Then, on my command, Sergeant "Bolrok" chose a number of men, with whose help he arranged those people (the Jews) in rows of four, led them to a clearing in the forest, and had them all shot. I personally did not shoot the Jews, but when I entered the clearing after the execution, the view was very shocking. They lay in that clearing, shot dead, men and women alike. Then I gave an order to search them, and put their shoes and clothes on the wagon and bring them to the detachment, which was carried out. I even accepted from the soldiers a few American dollars they found in the dead Jews, but after returning to the quarters, I gave them to "Zawisza," along with other items taken during the operation. I do not know who the Jews were and how they came to live in the forest, because even in their huts I did not talk to them.

\section{Testimony of Edward Sternik ${ }^{92}$}

As regards the shooting of Polish citizens of Jewish origin in the Siekierno forest, I state as follows: in 1944, my direct superior, "Zawisza," summoned me and said that the Home Army troops had been concentrated in the Siekierno forest, that the Germans had been investigating that grouping, and therefore they had sent a unit of Jews to the forest, with the task to help the Germans to investigate the troops. He said that he had one member of the group who would take us to the forest and show us where they were, and that the group should be eliminated. I asked "Zawisza" to release me from that order but since "Zawisza" refused I had to obey his command. Upon arrival, we gathered the Jews. I talked to alias "Bolrok" and asked him whether he would be able to carry out that com-

${ }^{92}$ AIPN, GK, 411/216, Protokół przesłuchania z 25 VIII 1949 r., podprokurator Sądu Okręgowego w Kielcach M. Górski [Typescript of the interrogation dated 25 August 1949, assistant prosecutor of the District Court in Kielce M. Górski], p. 174. 
mand. "Bolrok" agreed and I left. How "Bolrok" carried out the order, I cannot describe, because I did not see it.

\section{Testimony of Edward Sternik at the main hearing ${ }^{93}$}

At one point, I was summoned by "Zawisza," who said that there was a group of people in the Siekierzyn forest, most likely Jews, that reports on the activities of the Home Army to the Germans, and that they were working against us, so we had to gather a group of men in the form of one platoon, and from other detachments, and go with them to the forest in Siekierzyn. When I heard the order to go to an execution and elimination, as this is what "Zawisza" told me, that I was to eliminate those people, I asked him to relieve me of that obligation, as I could not undertake it, explaining at the same time that I had come to the forest to fight in open combat against the Germans, not helpless people. "Zawisza" would not relieve me, however, and he ordered me to carry out his orders without objections. He commanded us to take only machine guns. "Zawisza" gave that command to me, Stec was at the field practice at the time, so I took my platoon and the ones assigned to it, and set off. Along the way, we were joined by Stec with his soldiers, and we marched on. We were shown the way by a young man, I do not know if he was a Jew. In the forest, we saw huts and probably then I gave orders to surround them. Only then did I tell the soldiers that "Zawisza" ordered us to eliminate that group, and I asked if there were any volunteers. Bojlrok stepped out, accepting to carry out that order. Before that, I had asked Śledź, who flatly refused. I do not know what the elimination was like, because I just walked away and went into the forest. Olsza also asked to be relieved from this duty, which I granted. After the execution, I returned and repeated "Zawisza's" order to strip the dead of their footwear and clothes, because there were people in our detachment who had no shoes. When we were taking their shoes off, a messenger came from "Zawisza," telling us to return to the headquarters immediately, because the detachment was in danger from the Germans. I gathered the men and immediately we marched to the Home Army detachment. I know that the order was wrong. I gave a lot of thought to that order. I was at a crossroads, whether those people were actually guilty or not. "Zawisza" told me that they were people, who were to investigate the Home Army activity. Even then it seemed like a strange reason to me, the best proof is that I asked the commander to relieve me from that obligation. On the other hand, when "Zawisza" refused to relieve me, I knew that the order of the commander must be executed, so I could not refuse to carry it out. I only did what I had to, because failure to follow an order was punishable by court-martial. Today I realize that I was innocent in that case, because I opposed "Zawisza" against going on the operation and asked him to release me

${ }^{93}$ AIPN, GK, 217/45, Protokół rozprawy głównej przed Sądem Apelacyjnym w Kielcach w dniach 21-23 II 1950 r. [Typescript of the main hearing at the Court of Appeal in Kielce on 21-23 February 1950], p. 92. 
from the obligation. The only thing I could do after he had refused was to pull out a gun and take my own life, or to go. But personally I did not want to take part in the murder, did not want to force anyone to participate, which is why whoever asked me to be relieved, I consented. Going to the forest, I knew that I was going to eliminate a group of people, among whom there could be Jews. I knew that we were going to the real group, as we were led by a guide who, as "Zawisza" said, was also in that group. If I had known that they were Jews and innocent, I would have thought twice before carrying out the order. During the execution I was not quite sure if all those people were Jewish, because it was in the forest, where the visibility was reduced. I did not talk to them, and I had no orders to investigate them. "Zawisza" had not told me that those were the people who had escaped from a German camp. There were several women among them, but I saw no children. [...] I did not think about it at the time [whether] shooting those people would help the German authorities. I did not provide such help to the Germans. I joined the Home Army in order to fight in the open against the Germans. Doing other work, I was only following orders. [...] I cannot answer if a court-martial would have revoked a penalty for failing to follow the commander's order. I cannot remember the Rules of Procedure of the Polish Army. I graduated from a cadet school in 1936. I find it difficult at the moment to answer the prosecutor's question if I would have chosen a death sentence by the court-martial, or the judgment of the court today.

\section{Testimony of Jan Górski ${ }^{4}$}

Returning from practice in the afternoon, on the way to our quarters, we met "Grzegorz," who was waiting for us with the rest of his platoon, and several other men from the company. "Grzegorz" stopped us and told us to join them, and we walked about five or six kilometers into the forest. Initially, I did not know where and why we were going. We were led by one or two Jews, who were walking at the front of the troops. The commanding officer was Second Lieutenant "Grzegorz." When we approached the camp where the Jews were, "Grzegorz" instructed us to break up into two groups, one of which he commanded, and the other - "Zygmunt." Then we were told that we were going to a camp where there were Jews, and they would be executed, but I cannot remember exactly in which group I was, "Zygmunt's" if I am not mistaken, and we went straight to the camp. At the same time, "Grzegorz's" group surrounded the camp from the other side and partially entered, so I [saw?] "Grzegorz" in the camp as well. At the time when "Zygmunt," while in the camp, said to the Jews that if they wanted they could go with us to the detachment, shots rang out from the side. As it turned out "Bolrok" (sergeant) fired a blast from his machine gun injuring two Jews who

${ }^{94}$ AIPN, GK, 411/216, Protokół przesłuchania z 11 V 1949 r. w WUBP w Kielcach, oficer śledczy Marian Duda [Typescript of the interrogation dated 11 May 1949 at the WUBP in Kielce, investigating officer Marian Duda], pp. 186-187. 
probably wanted to run, for which "Grzegorz" of course scolded him on the side, because it was too early. The two wounded and two others whom "Grzegorz" ordered to tend to their injuries were left on the side, and "Grzegorz" commanded me, "Jordan," and a third one whom I did not know to watch them so they did not to run away, and when we heard shots we were to shoot them as well. The rest of the Jews, according to the statement by "Zygmunt," under the pretext of joining the detachment, were arranged in a row and shot while marching. Having stayed with the four Jews, when the shots rang out, I shot them. According to "Grzegorz's" orders, we searched the four shot Jews, and several hundred zlotys and one pair of shoes that we found were given to "Grzegorz." It is difficult to determine how many Jews were shot; I guess that about forty or fifty, including several women and one or two children. Other Jews were also searched, and their clothes and shoes were taken to the detachment. The bodies were dragged from the clearing to the edge of the forest and left there, unburied.

\section{Testimony of Jan Górski on the main hearing ${ }^{95}$}

At one point I heard several shots. As it turned out, "Bojlrok" shot and injured the Jews who came with us as guides. "Grzegorz" then turned to Bojlrok and chastised him for shooting on his own. The wounded shot by "Bojlrok" stayed there, no one bandaged them, and either "Grzegorz," or "Bojlrok," I do not remember, told me to watch them with a few soldiers, telling me also that, once the execution started in the forest, I was to shoot the four or five I was left with. As ordered, I stayed with "Jordan" and another man, while the rest of the unit went forward. I do not know how the execution was conducted because I was not there. As soon as we heard shots in the forest, one of my soldiers, I think it was "Jordan," shot the four Jews left with us. I did not shoot them then. The order to shoot was given, I think, at the briefing, when "Bojlrok" had already volunteered to carry out the order, so it was likely to be "Bojlrok" who gave me the order to shoot the four. As "Grzegorz" commanded, we stripped the dead of their shoes and searched their clothes. Later, when I went to the place of execution, I saw about 50 bodies, including, it seems, women and children. Again, I would like to explain that I was not the one who shot the four Jews, only the soldiers who were with me had shot them.

\section{Testimony of Jan Stec at the main hearing ${ }^{96}$}

We walked into a clearing where we saw huts and people coming out of them. We did not have any briefing then. I did not know exactly what we would be doing. [...] We realized that they were Jews. I turned to "Grzegorz" asking if it was per-

${ }^{95}$ AIPN, GK, 217/45, Protokół rozprawy głównej przed Sądem Apelacyjnym w Kielcach w dniach 21-23 II 1950 r. [Typescript of the main hearing at the Court of Appeal in Kielce on 21-23 February 1950], p. 92.

${ }^{96}$ Ibidem, p. 93. 
haps possible not to carry out that order, and "Grzegorz" told me that "Zawisza" gave a strict order. "Grzegorz" then addressed everyone, asking who would undertake to carry it out. "Bojlrok" volunteered, along with several other men. Not waiting to see what would happen after, I left, so I do not know how the execution was carried out. I did not take any part in it, I went into the forest. When we had been marching into the forest, I saw two guides at the head of the column, but I do not know who those people were. [...] I know that "Grzegorz" did not "enjoy" that act. He took it as a necessity caused by the harsh and strict command of Zawisza.

14. Testimony of Jan Śledź at the main hearing ${ }^{97}$

"Grzegorz" told us about the order we had to carry out and asked me whether I would accept to carry out the order. I told him that I would have nothing to do with that, and I walked away. Then "Bojlrok" volunteered, immediately taking command of the operation. [...] How many Jews were then shot there, it is difficult for me to answer. Men in the detachment said later that supposedly there were children there as well. This case had a negative effect on men in the detachment, it was clear that they were displeased, and this is perhaps why little was said about it. [...] At the briefing, I categorically refused "Grzegorz" to take any active part in the operation, which I could not accept. I suffered no repercussions on that account. [...] He [Sternik] did not give a military command, which I would have been forced to obey, but asked if I wanted to volunteer myself. When I refused, I did not experience any problems on this account, neither from him, nor anyone else. After this incident [he] left our detachment, he was probably removed by the district command. The detachment said that the business with the Jews hurt him very much. Who "Zawisza" was I do not know.

15. Testimony of Władysław Cybula at the main hearing ${ }^{98}$

After the incident in the Siekierno forest, I saw "Bojlrok" with some footwear. I personally never saw him with any rings, I was only told about this by soldier "Wampir." The rings were allegedly stolen from "Bojlrok" later. I suppose that Private "Wampir" was present at the operation in Siekierzyn and knew that it was there that "Bojlrok" took those rings.

\section{Biographical notes ${ }^{99}$}

Władysław Cybula (alias Cebula), “Grzmot” (1921-?), from Bodzechów, a farmer with his own farm. He had seven years of schooling. In the Home Army since April 1943, recruited by Józef Radomski "Robak," later in the detachment

\footnotetext{
${ }^{97}$ Ibidem, p. 94.

${ }^{98}$ Ibidem.

${ }^{99}$ All biographies are based on a person's own testimony, the testimonies of witnesses, trial records, and available literature.
} 
of "Topór" and "Zawisza," in Kolasa's squad as a LMG gunner, later in "Longin's" platoon. After the war, he worked on the land; in 1949 he joined the United People's Party. He took part in the murder of Jews in Goździelin. Sentenced by the Court of Appeal in Kielce on 25 February 1951 to "life imprisonment, deprivation of public and civic rights forever, and forfeiture of all his property"100. The same sentence was passed for Władysław Kolasa and Ryszard Nowacki. On 11 September 1950, the judgment under appeal was upheld by the Supreme Court in Warsaw ${ }^{101}$. The Supreme Court in Warsaw decided on 19 January 1957 to reduce Cybula's sentence to 10 years in prison. Three months later, on 15 March 1957, the Regional Court in Kielce, at the request of the prosecutor and based on his good behaviour in prison, ruled his conditional parole. On 21 January 2000, the District Court dismissed the application of Cecilia Cybula of 20 July 1998, in which she sought the annulment of the earlier decisions.

Jan Górski, “Rzędzian” (1922-?), came from the village of Jagnin, Opatów county. He was born into a family of landowners. After the war he lived in Poznań, where he studied at the Academy of Medicine. He joined the Union for Armed Struggle-Home Army (Zwiq̨zek Walki Zbrojnej - Armia Krajowa, ZWZ-AK) in June 1942, and then was in the detachment commanded by "Mruk," and later "Topór" and "Zawisza." While serving under "Topór," he was a squad commander, with "Zawisza" - deputy platoon commander, until demobilisation. Shortly after the war, he was briefly arrested by the Security Bureau (Urzqd Bezpieczeństwa, UB) on suspicion of involvement with the "Freedom and Independence" (Zrzeszenie "Wolność i Niezawisłość", WiN). Tried for the crime in the Siekierno forest along with five other accused by the Court of Appeal in Kielce, he received the harshest sentence - the death penalty. He was pardoned later and the death sentence was commuted to life imprisonment. On 11 September 1950, the sentence was upheld by the Supreme Court. On 12 December 1957, the Supreme Court, following extraordinary appeal submitted the Public Prosecutor General of the Polish People's Republic, commuted to eight years in prison; at the same time, the Court credited Górski's time served under arrest and in prison since 28 April 1949 towards his sentence of imprisonment, thus recognizing the sentence as served.

Stanisław Kawecki, “Lech” (1919-?), born in Chocimów, Opatów county. He was born to a family of landowners. He joined the detachment of "Mruk" in February 1944, two days later the commander was replaced by "Topór." "Lech" served in the rank of rifleman in "Gryf's" squad, then "Mikołaj's" - a Russian.

${ }^{100}$ AIPN, GK, 217/45, Sentencja wyroku Sądu Apelacyjnego w Kielcach z 25 II 1951 r. [Judgment of the Court of Appeal in Kielce of 25 February 1951], p. 215.

${ }^{101}$ AIPN, GK, 217/46, Sentencja wyroku Sądu Najwyższego w Warszawie z 11 IX 1950 r. [Judgment of the Supreme Court in Warsaw of 11 September 1950], pp. 8-22. 
After the war he worked in the traffic department of the Municipal Council, taught in school, worked as a technician in Starachowice (in the mining industry), and was socially active in the trade unions. For his involvement in the murder of the Jews in the Siekierno forest, he was sentenced by the Court of Appeal in Kielce to eight years in prison ${ }^{102}$. This judgment was upheld by the Supreme Court on 11 September 1950. On 28 July 1993 the Provincial Court in Kielce rejected Stanisław Kawecki's application for the annulment of conviction for participation in the crime. This ruling was upheld by the Court of Appeal in Kraków. His attorney then appealed for a revision of the judgment of the Court of Appeal (25 February 1950) and the Provincial Court (28 July 1993) in Kielce. The Supreme Court ruled on 16 February 1996 and 10 February 1999, to dismiss these applications. In subsequent years, Kawecki's representatives did not to relent in their efforts to exonerate their client, but to no avail ${ }^{103}$.

Władysław Kolasa, “Leń” (1909-?), born in Grójec, Opatów county, resident in Opatów, graduate of two courses of a teachers' academy. After the war, he worked as a warehouseman. He joined the ZWZ-AK in November 1942, serving in a detachment guarding the estate of Kaliszany, where the Home Army HQ was. Kolasa was there in the platoon of Lieutenant "Dąb," subject to the $2^{\text {nd }}$ Department (intelligence). Later, he was in the detachment of "Topór" and "Zawisza" as squad commander in the rank of corporal. After the war, the Military Court in Kielce sentenced him to life imprisonment for illegal storage of weapons. For

${ }^{102}$ AIPN, GK, 217/45, Sentencja wyroku Sądu Apelacyjnego w Kielcach z 25 II 1951 r. [Judgment of the Court of Appeal in Kielce of 25 February 1951], p. 135. For his involvement in the action against a detachment of the People's Army in January 1944 in Wólka Bodzechowska, he was sentenced to five years and six months of prison. The entire sentence was ten years.

${ }^{103}$ The ruling of the Supreme Court dated 21 October 1999 reads, "Currently, the defender of the convicted has filed another motion for reopening of the case, requesting the repeal of the Supreme Court judgment of 11 September 1950, ref. K 783/50 and the judgment of the former Court of Appeal in Kielce dated 25 February 1950, ref. CI 108/49, which sentenced Stanisław Kawecki on the basis of art. 1 of the Decree of 31 August 1944, to eight years in prison and additional fines; the defense also requests the case to be referred to the competent court for reappraisal. The basis for the subsequent application is, according to the defense, new evidence in the testimonies of witnesses Jan Ziółkowski and Jan Pękalski, who can testify that 'the convicted was not subordinate to the group commander Edward Sternik from 14 until 16 August 1944 and therefore could not and did not participate in the liquidation of the Jewish people."' The Supreme Court ruled this application as unfounded. The same Court found, however, that "the view expressed by the Supreme Court in the decision of 10 February 1999, ref. IV KO 90/98, deserves to be fully approved, as the view presented in the earlier decision of 16 February 1996, ref. III KO 43/95, in which the Supreme Court dismissed the motion to reopen the case, finding that the confirmation that Stanisław Kawecki carried out a personal task ordered by the commander of the grouping did not exclude the participation of the convicted in the incident in which he was said to take part as per item VI b of the judgment of the former Court of Appeal in Kielce, dated February 25 1950" (ibidem, pp. 7-9). 
participation in the murder of Jews in Goździelin and the Siekierno forest, on 25 February 1951 the Court of Appeal in Kielce sentenced him to "life imprisonment, deprivation of public and civic rights forever, and forfeiture of all his property." ${ }^{104}$ The judgment was upheld by the Supreme Court in Warsaw ${ }^{105}$. On 13 March 1957 the Provincial Court in Kielce reduced Kolasa's sentence (as well as Nowacki's) to 10 years in prison and credited his time served under arrest and in prison since 20 January 1949 towards his sentence of imprisonment.

Ryszard Nowacki, “Pobożny” (1921-?), born in Ćmielów, merchant by profession, he had four classes of trade school. He joined the Polish Partisan Association (Polski Zwiqzek Powstańczy) in 1940, since 1942 in the ZWZ-AK; he was subordinate to the $2^{\text {nd }}$ Department in Ćmielów (under Józef Radomski "Robak"). In December 1943, he was sent to guard the Kaliszany estate. After the war, he was sentenced by the Military Court in Kielce to 15 years in prison for involvement with the WiN. He took part in the murder of Jews in Goździelin, for which the Court of Appeal in Kielce sentenced him to "life imprisonment, deprivation of public and civic rights forever, and forfeiture of all his property."106 On 11 September 1950, the judgment under appeal was upheld by the Supreme Court in Warsaw $^{107}$. On 22 May 1951 the Provincial Court in Kielce sentenced him to life imprisonment. The case was re-examined after the amnesty of 27 April 1956. On 13 March 1957 the Provincial Court in Kielce reduced Nowacki's (and Kolasa's) aggregate sentence to 10 years in prison and credited his time served under arrest and in prison since 25 November 1946 towards his sentence of imprisonment.

Kazimierz Olchowik, "Zawisza” (1910-1979), was born in Grodno, Białystok region. In 1929, he graduated from the Adam Mickiewicz All-Boys' State School in Grodno, and then for three terms he studied at the Faculty of Medicine of the Stefan Batory University in Vilnius. After serving the compulsory military service in 1932-1933, he found work in the penitentiary system, where he was an assistant to the chief warden of the Lwów prison (Brygidki), and since 1936, he served as a chief warden in Dobromil (Lwów region). On 1 January 1935, he was promoted to second lieutenant of the reserve. On 23 August 1939, he was called up to the $5^{\text {th }}$ Podhale Rifles Infantry Regiment in Przemyśl, which fought in the September Campaign under the $22^{\text {nd }}$ Mountain Infantry Division (Kraków Army). As platoon commander and deputy company commander, Olchowik took part in the Battle of Owczary near Busko-Zdrój. On 9 September 1939, according to his own account, he was supposed to be promoted to lieutenant; a day later he was captured by

\footnotetext{
${ }^{104}$ AIPN, GK, 217/45, p. 215.

${ }^{105}$ Ibidem, 217/46, pp. 8-22.

${ }^{106}$ Ibidem, 217/45, p. 215.

${ }^{107}$ Ibidem, 217/46, pp. 8-22.
} 
the Germans in Rytwiany. He was a POW for six weeks (from 10 September to 27 October), after which he was released. He was hiding as an unregistered officer in Opatów District. In October 1942, he joined the Home Army and received an assignment to the $2^{\text {nd }}$ Department of the Radom Region, with the task of organizing intelligence and fighting squads. In May 1943, he was sent to Świętokrzyskie Mountains, where - among other things - he trained the Home Army soldiers in the Ostrowiec Świętokrzyski Sub-district (code "100").

On 18 February 1944 he was arrested by the Germans and imprisoned in Ostrowiec Świętokrzyski. After several days, the Germans released him. He told his colleagues that they returned his gun to him (!). According to the testimony of Władysław Kolasa, he mentioned "Mruk." The scars on both wrists were his trademarks, a result of attempted suicide while in the custody of the Gestapo. After being released from prison at the end of February 1944, he joined the "Barwy Białe" detachment, where he served as a training officer, replacing "Topór" on 1 April 1944 as commander of the detachment. "Zawisza's" detachment, numbering about 250 men, joined the $2^{\text {nd }}$ Legions Infantry Regiment of the Home Army; Olchowik was the commander of the $5^{\text {th }}$ Company until September 1,1944 . After the $2^{\text {nd }}$ Legions Infantry Regiment of the Home Army was disbanded on October 12,1944 , Olchowik was appointed the commander of the $2^{\text {nd }}$ Battalion with the task to lead it the area of Świętokrzyskie Mountains and disband it there. At the end of December 1944, "Zawisza" came to Kolasa's house dressed in civilian clothes and showed him a Parabellum pistol and a German licence for its possession. On 8 January 1946 he left Poland and reached Murnau (Bavaria, under the administration of the U.S.), where he was provisionally verified by the Home Army Soldiers Verification Committee. From there he was sent to the Polish Military District in Schleswig-Holstein, in Wentorf (British zone of occupation), where he underwent another verification. Finally, he was validated for his underground service from 1 October 1942 until 15 January 1945 and the rank of lieutenant obtained during the war. From Germany, Olchowik travelled to England and then to Australia, where he died.

Józef Radomski, “Konrad," “Robak” (1907-?), born in Krasnoyarsk (Russia), received secondary education in economics, came from a working class family. Head of the $2^{\text {nd }}$ Division of the Home Army in Ćmielów, his deputy was "Grażyna." After the war he lived in Starachowice, where he worked as an auditor in the Labor Cooperative in Kielce.

Stanisław Różalski, “Grażyna” (1902-?), from a peasant family, completed seven years of primary school. He took part in the Polish-Bolshevik War of 1920. He spent two years working in the Borderlands at forest clearing and building houses, and in 1923 he was drafted into the army, where he served as a regular non-commissioned officer until 1939. He earned the rank of sergeant. He joined the Underground in 1941 through "Kościesza" (John Doe). During the in- 
terrogation, he maintained that initially he did not know what kind of organization he had joined. During the occupation, he lived in Ćmielów, where he had a shop with beer and sweets, serving as a contact box for the Underground. He was deputy of Radomski "Robak" - the head of "number two" in Ćmielów. At the end of December 1944, he was arrested by the Gestapo in Ostrowiec, but later released after "Robak's" intervention. He took part in the murder of Jews in Goździelin. After 1945, he went into hiding, he worked as an out-worker; he was making and selling textile haberdashery. It was only in 1959 that his place of residence was established (Legionowo, Nowy Dwór Mazowiecki county and he was indicted. On 26 February 1959 the Provincial Prosecutor's Office in Kielce issued a decision on his detention on remand. The Provincial Court in Kielce, Radom Branch, passed a judgment on 25 March 1960, sentencing him to seven years in prison and three years of deprivation of public rights. He applied for revision of the judgment, seeking a reduction of the sentence on the grounds that "he was brought up to follow the orders blindly." On 11 November 1960 the Supreme Court in Warsaw ruled that there were no grounds for a revision of the accused Różalski. ${ }^{108}$

Kazimierz Rudziński (Rudnicki?), "Bolrok," sergeant, came from the area of Baćkowice or Raków, he was about 36 years old in 1944. He joined the "Barwy Białe" detachment in 1944 in Szumsko (Szumsko-Raków), immediately taking the position of non-commissioned officer of arms. He was on first name basis with "Zawisza," so they likely had met earlier. He was probably a regular noncommissioned officer in the rank of platoon commander. The Home Army command trusted him. He took part in the murder of Jews in the Siekierno forest, but he was not tried. His post-war fate is unknown.

Witold Sągajłło, "Felix," “Sulima," “Sandacz," “Tarło” (1910-1998), Acting Sub-Lieutenant since 1931, Sub-Lieutenant since 3 May 1935. Since February 1940, he was involved with the ZWZ in the Radom and Kielce Region. From May 1941 until April 1944, he was the commander of the ZWZ-AK in the Opatów District (in 1943, he was promoted to [Navy] Lieutenant). In September 1945, he arrived in Prague, Czech Republic, where he received a permit to go to Pilsen in the American zone. He was in transit camps in Cham [Hamm], Regensburg and Murnau. On September 26, 1946, he was enlisted in the Navy as Lieutenant. He moved to England and lived in London (see memories: Witold Sągajłło, The Man in the Middle: A story of the Polish resistance 1940-45, London 1984, passim).

Jan Stec, "Zygmunt" (1912-?), born in Prusy, Opatów county, into a peasant family. He worked in the civil service. In 1934, he graduated from a teach-

${ }^{108}$ AIPN Ra, 29/138, Akta w sprawie karnej Stanisława Różalskiego [Files of Stanisław Różalski's Criminal Case], p. 11. 
er training college, and in 1935, he served the compulsory military service, which he completed in the rank of second lieutenant. He could not find work as a teacher and until 1939 he was forced to work as a laborer in the Starachowice Industrial Plant. He joined the underground organization in the autumn of 1942. He was a deputy of Edward Sternik (platoon commander). He joined "Zawisza's" detachment in July 1944 but he spent only a total of three weeks there, after which time he transferred to another unit. During the war, he used documents issued under the name of Wacław Kawiński. On 25 February 1950 Jan Stec was sentenced to five years and one month in prison for participating in the murder of Jews in the Siekierno forest. On 11 September 1950, the Supreme Court acquitted him of the charge of involvement in this crime. On 14 November 1997 the District Court in Kielce did not consider the application of Halina Stec, which demanded the annulment of the judgment of the Court of Appeal. On 10 April 2000 the District Court in Kielce awarded the Stec family (Stec's widow and his two children) compensation from the State in the amount of 2,781 zlotys per person and damages in the amount of 10,000 zlotys for each person $^{109}$.

Edward Sternik, "Majewski," “Grzegorz" (1914-?), born in Bodzechów, Opatów county, where he lived before the war. He was an officer of the Polish Army before 1939, in the rank of second lieutenant. He graduated from cadet school in 1936. He took part in the 1939 September campaign, fighting in the battle of Zamość (as a regular soldier). In Terespol, he was taken prisoner, but later managed to escape. He was a teacher by profession. During the war, he also used documents issued under the name of Henryk Dębinak. Member of ZWZ-AK since the beginning of 1940, he belonged to a six-person group Active Combat Organization (Organizacja Walki Czynnej). He joined "Zawisza's" detachment in May 1944; he served as a training officer and platoon commander. After the concentration of the Home Army, he was commander of the $1^{\text {st }}$ Platoon in the $2^{\text {nd }}$ Company of the $2^{\text {nd }}$ Battalion of the Home Army. In 1949 he was the headmaster of school in Górzyn, Krosno county. Since 1946 a member of the Polish Socialist Party (Polska Partia Socjalistyczna, PPS), and then the Polish United Workers' Party (Polska Zjednoczona Partia Robotnicza, PZPR). For his involvement in the murder of "Miś" and the crime scene in the Siekierno forest, on 25 February 1950 the Court of Appeal in Kielce sentenced Sternik to death. On 19 February 1951 Bolesław Bierut changed the death sentence to life imprisonment. On 19 January 1957 the Supreme Court reduced his sentence to 10 years in prison.

${ }^{109}$ AIPN, GK, $217 / 45$, p. 13. The family of Jan Stec demanded the amount of 209,502 zlotys as compensation and damages for the period of detention from 19 April 1949 until 11 September 1950 (ibidem, p. 14). 
Konrad Suwalski, “Cichy," “Mruk” (1917-1945) came from Silesia but lived in Ćmielów. His father was the head of an iron ore mine. Several years before the outbreak of war, "Mruk" graduated from the Academy of Mining. He served in the Polish Army, achieving the rank of lieutenant. Organizer and first commander of the "Barwy Białe" detachment, which he commanded until the February 1944. In the summer of 1944 he was in the $1^{\text {st }}$ Company of the $2^{\text {nd }}$ Battalion of the $2^{\text {nd }}$ Legions Infantry Regiment of the Home Army, on the way to bring reinforcements to the Warsaw Uprising. In 1945 he remained in hiding, but in April he was recognized on the street in Kielce and arrested by the Security Bureau After several months of brutal interrogation, he was brought before the District Military Court in Łódź at the session in Kielce. He was sentenced to death by firing squad, and deprivation of civil and public rights forever. He was executed in August 1945 at the Jewish cemetery in Kielce. In the early 1990s, Konrad Suwalski was posthumously rehabilitated and decorated with the Cross of Valour and the Home Army Cross.

Jan Szpinek, “Motyl” (1904-?), born in Czachów, Opatów county, in a working class family. He completed four classes of middle school. Regular staff sergeant, head of "number two" in the Ćmielów Home Army Sub-district. Accused of ordering the murder of the Jews in Goździelin. On August 31, 1944, the Provincial Court in Kielce sentenced him to 10 years in prison and deprivation of civil rights and public rights for a period of 10 years ${ }^{110}$. On 8 December 1952 the judgment was upheld by the Supreme Court in Warsaw. On 6 March 1958 the same Supreme Court, after an extraordinary appeal submitted by the Minister of Justice, rescinded the previous judgment, on the grounds that the trial court was based solely "on the testimony and statement of a witness, Stanisław Tworek" which "cannot be sufficient and convincing evidence as to the guilt of the accused."

Jan Śledź, “Jeleń” (1918-?), born in Jurkowice, Sandomierz county, civil service official, completed six years of middle school. Until March 1944, he worked in the Ostrowiec Industrial Plant as a welder. He joined the partisan troops in March 1944 as a sergeant major instructor. After the war, he served on the Board of the City of Szczecin. In 1946, he was sentenced by the Military Court in Szczecin; he was released from prison in 1947. For participation in the murder of "Miś" and the crime in the Siekierno forest, he was sentenced by the Court of Appeal in Kielce on 25 February 1950 to a total of five years and one month in prison.

${ }^{110}$ AIPN Ki, 9/126, p. 39. It was the trial of members of the command of the $2^{\text {nd }}$ Department of the ZWZ-AK in the Opatów District, including Zenon Krzekotowski, Władysław Banaszak, Józef Radomski, and Michał Pytlak. 
Stanisław Tworek, “Jaszczurka” (1908-?), born in Bodzechow, completed four years of middle school, metalworker by profession. He did not serve in the military. He joined the ZWZ-AK in December 1941. He collected information, which he then reported to "Robak." In the Home Army, he was also a vehicle service instructor. After the war, he worked at Bodzechów State Farm as a metalworker and mechanic. He bought a truck, which was his source of income, also had a locksmith's shop. In the period of 19 March - 6 July 1949 he was a secret collaborator of the County Office of Public Security (Powiatowy Urząd Bezpieczeństwa Publicznego, PUBP) in Ostrowiec Świętokrzyski (he had a codename "Kot"). Removed from the list of secret collaborators for lack of cooperation. He took part in the murder of Jews in Goździelin. On 30 June 1949 he was detained and then released. On 6 April 1959, he was sentenced by the Provincial Court in Kielce, Radom Branch to a total penalty of 10 years in prison and deprivation of rights for a period of five years. On 12 April 1961 The Supreme Court, pursuant to art. $8 \S 1$ of the amnesty act of 27 April 1956 decided to discontinue the proceedings against Tworek ${ }^{111}$.

Karol T. Wickenhagen (1901-1952), captain of the cavalry reserve. Since 1942, at the order of the Main HQ of the Home Army, he ran an underground cadet school at his estate in Sobótka - $1^{\text {st }}$ Cavalry Regiment of the Home Army. During this time, he also entertained many powerful Germans at home. In July 1943, he helped establish contacts between a commander of a detachment of the National Armed Forces (Narodowe Siły Zbrojne, NSZ), Wachtmeister (Sergeant) Tomasz Wojcik "Tarzan" (officially employed as a foreman), and Lt. Leon Torliński "Kret" of the Home Army. In the late 1944, a joint conference was held in Sobótka with the German authorities, officers of the Home Army Sandomierz Inspectorate, and Major Leonard Zub-Zdanowicz of the NSZ. During the conference, the Germans proposed a ceasefire to the Poles and directing combat against the Communists. The proposal was refused ${ }^{112}$.

Henryk Wierzbiński, “Topór,” “Toporek” (1918-?), born in Jędrzejowice, Opatów county, clerk, welder by profession, he completed two classes of middle school. He was recruited in the ZWZ-AK in the winter of 1941 by Jan Śledź "Jeleń." He took the oath before Roman Rożyński "Róg." At first, he was assigned to the outpost in Ostrowiec, where he recruited new people, then - to the Częstocice outpost, the commandant of which was Tadeusz Mitelsztet "Turek." In January 1944, he was exposed and had to go into hiding. He was appointed an instructor in Mikrowice - he was training men for an armed unit (woodland

${ }^{111}$ AIPN Ki, 005/358, Ministerstwo Spraw Wewnętrznych, Biuro "C" [Ministry of Internal Affairs, Bureau “C”], p. 5.

112 More on this subject, see Marek Jan Chodakiewicz, Narodowe Siły Zbrojne - "Ząb" przeciw dwu wrogom ( $2^{\text {nd }}$ edition, extended, Warsaw: Fronda, 1999), 147. 
guerrilla warfare). He trained six men, all of whom joined the forest detachment under the command of "Jeleń" (Śledź). On 6 June 1944 he was admitted to "Zawisza's" detachment as an instructor in the rank of corporal. Until 21 August 1944 he was commander of the $5^{\text {th }}$ squad. Later he became ill and resigned, he stayed in a "den" in the house of the head of the hamlet of Rusinów [such a name is found in the case files, although there is no such village in this area; perhaps it Ruszków - J.M., A.S.], then, until the liberation, with his mother in Jędrzejowice. As the commander of the $5^{\text {th }}$ squad, he took part in the concentration in early August near the village of Dębno and Jeziorko, Nowa Słupia county, from where the troops set for Warsaw. After the war he lived in Koszalin. Before he went there, he was briefly a police officer (police school instructor in Ostrowiec). In the years 1945-1948, he was a member of the PPS. On 25 February 1950 he was sentenced by the Court of Appeal in Kielce to 15 years in prison and the loss of rights for ten years. On 19 January 1957 the Supreme Court in Warsaw reduced the sentence to eight years in prison, and on 26 March 1957 the Provincial Court in Kielce granted him conditional parole.

Władysław Zwiejski, “Jaruga” (1908-1998), born in the village of Ruszków, Opatów county, in a peasant family. After graduating from middle school in Ostrowiec in 1928, he served compulsory military service in the Reserve Infantry Officers School in Gródek Jagieloński (1928-1929), and then studied at the Law Faculty of the University of Warsaw. In the years 1934-1937 he worked at the Tax Office in Krzemieniec, and in 1937-1939 he was a legal clerk at the Krzemieniec Secondary School. During the 1939 defensive war, he was a platoon commandant with the rank of lieutenant. After the September defeat, he returned to his family and became involved in the underground peasant movement; he was a member of the "Roch" People's Party (Stronnictwo Ludowe "Roch") and the commander of District "6" (Opatów) of the Peasant Battalions. After the liberation, in the years 1945-1949 he was involved with the Polish People's Party (Polskie Stronnictwo Ludowe, PSL), and later the United People's Party (Zjednoczone Stronnictwo Ludowe, ZSL). Oppressed by the authorities, he left his family and moved to the town of Pasłęk, where he found employment in the judiciary, and then worked as a solicitor. Author of the book Walczyli w Chłopskich Batalionach [They Fought in the Peasant Battalions], Warsaw 1964, in which he described the establishment and activities of the Peasant Battalions in the Opatów District.

Translated by Katarzyna Gucio

\begin{abstract}
The soldiers of "Barwy Białe" partisan detachment of the Home Army established in late 1943 in the Opatów District participated in at least several murders of Jews - the murders in Goździelin, Lisów and Siekierno forests are doc-
\end{abstract}


umented. The last crime was committed on 16 or 17 August 1944, when the detachment (at that time a part of the $2^{\text {nd }}$ Infantry Division) was marching to aid fighting Warsaw (as part of Operation Tempest). While stationed in Siekierno, the detachment's commanding officer Kazimierz Olchowik "Zawisza" issued an order to execute a large group of Jews (30-58 people) living in the nearby forest after their escape from a labor camp in Skarżysko-Kamienna. After World War II most participants of the murders were tried and punished. No punishment, however, was imposed on the detachment's commanding officer Kazimierz Olchowik, nor the sergeant, who went by the alias of "Bolrok" - the two men chiefly responsible for the murder in the Siekierno forests.

\section{Key words}

Jews, Home Army, the Kielce Region, the Opatów District, "Barwy Białe" detachment, the Radom-Kielce Sabotage Directorate (Kedyw), Goździelin, Lisów, Siekierno, Kazimierz Olchowik, "Zawisza," $2^{\text {nd }}$ "Pogoń" Division of the Home Army Legions, August decree 